\title{
A NEW SPECIES OF HAEMOPIS (ANNELIDA: HIRUDINEA): EVOLUTION OF NORTH AMERICAN TERRESTRIAL LEECHES \\ by \\ BETH ANNE WIRCHANSKY
}

A thesis submitted to the

Graduate School - Camden

Rutgers, The State University of New Jersey

In partial fulfillment of the requirements

for the degree of

Master of Science

Graduate Program in Biology

Written under the direction of

Dr. Daniel H. Shain

and approved by

Dr. Daniel H. Shain

Dr. Patrick J. Mcllroy

Dr. William M. Saidel

Camden, New Jersey

May, 2009 


\section{ABSTRACT OF THE THESIS}

A New Species of Haemopis (Annelida: Hirudinea): Evolution of North American

Terrestrial Leeches

\section{By: BETH ANNE WIRCHANSKY}

Thesis Director:

Dr. Daniel H. Shain

Among the relatively few terrestrial leeches known worldwide, only two (Haemopis terrestris, Haemopis septagon) are described from North America. Here we report a third terrestrial leech collected from the southern part of New Jersey, USA. Tissue samples were obtained from 14 individuals representing three populations, and morphological characters were scored after dorsal and ventral dissections. Maximum Parsimony and Bayesian Inference analyses resolved phylogenetic relationships within the genus Haemopis using cytochrome c oxidase subunit 1 (CO1), 12S ribosomal RNA (rRNA), and 28S rRNA gene fragments, establishing the monophyly of North American haemopids and terrestrialism as a synapomorphy for some members of the group. Geographic isolation, morphological distinctions and combined phylogenetic analyses support the designation of a new species of terrestrial leech, Haemopis ottae n. sp. Phylogeographic interpretations of the haemopid clade suggest that terrestrialism was derived from a northern, aquatic ancestor whose descendents were initially confined to Midwestern States and central Canada by the Appalachian Range. 
More recently, the terrestrial lineage diverged near the southern extent of its range and began a northeasterly migration along coastal states giving rise to $H$. septagon and $H$. ottae $\mathrm{n}$. sp., the latter of which appears to define the leading edge of a northward expansion. 


\section{DEDICATION}

I dedicate this thesis to my father, Dimitri Wirchansky. Although he isn't here to witness my success, I know that he would see it as another inevitable step in the journey to find my place in this world. His impact on me is immeasurable and I'm certain I wouldn't have had the fortitude to complete this task without 25 years of his insight and counsel. 


\section{ACKNOWLEDGEMENTS}

I thank Dr. Mark Siddall, Anna Phillips, and Frank Fontanella at the American Museum of Natural History for generous support and instruction in phylogenetic analyses, and Bill Moser of the Smithsonian Institution for his guidance and assistance in specimen identification and dissections. I am grateful to the Ott family for their curiosity and interest in a giant leech, and allowing us to collect specimens on their property. Finally, a special thank you to Jeff Schickling, Matthew Kail, Matt Niepielko, and the other volunteers for their enthusiastic assistance looking for leeches.

Dr. Shain, far more than an academic advisor, you have been a kind and patient mentor, gently showing me how to improve as both a scientist and an individual. You challenge me with a sense of quiet conviction and certainty in my success that has given me the confidence to do far more than I believed I was capable of. I appreciate the interesting talks about life and philosophy, spirited debates and a genuine desire to share your knowledge. To have an advisor who is invested in me, not just my project, is the highest privilege. Thank you so much.

I would like to thank my committee members, Dr. Patrick J. Mcllroy and Dr. William M. Saidel for taking interest in me and my work, and all of your kind words, patience and guidance as I worked to complete this degree. I am also grateful to all of the other graduate students in the department, with whom I have 
shared laboratory supplies, frustrations, and successes, in addition to life stories, coffee, and numerous good beers.

Finally, I am indelibly grateful to my friends and family for their continued unwavering support. I owe the most to my mother, Joann Wirchansky, who was there to give me encouragement, solace, and even shelter when I needed it most. To all of you who continued to believe in my abilities, even when I doubted myself, I am truly grateful and honored to have you in my life. I enrolled as a graduate student excited to learn and grow as a scientist, but as my time here ends, I realize that the changes have reached further than simply academic development. I extend my sincerest thanks to everyone who has been a part of this experience, and promise to repay my debt of gratitude by passing along what I have learned from each of you. 


\section{TABLE OF CONTENTS}

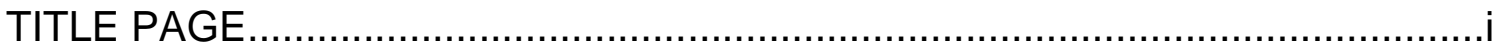

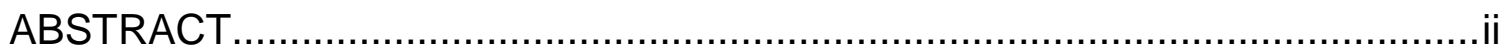

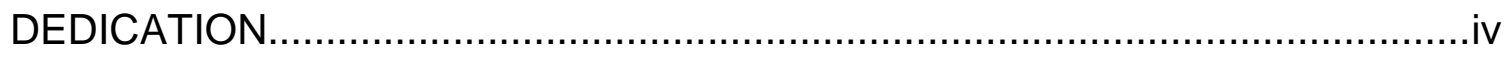

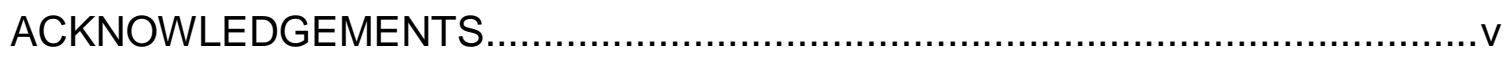

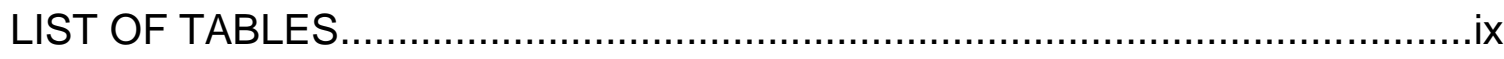

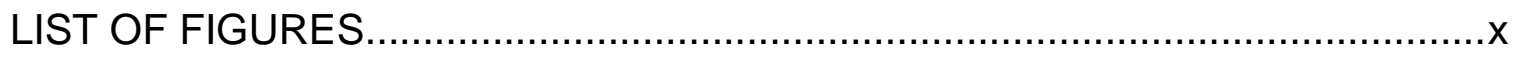

\section{SECTION}

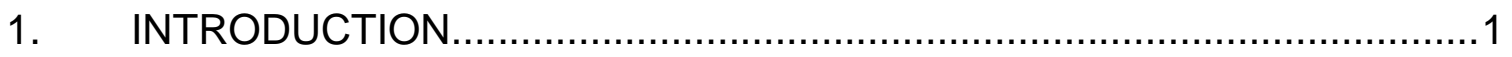

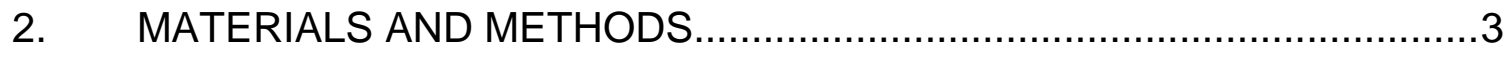

Specimen collection and maintenance.......................................

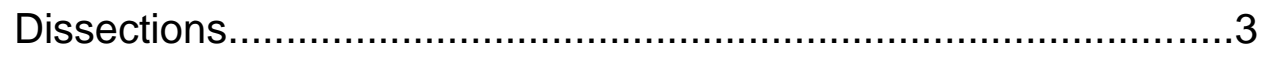

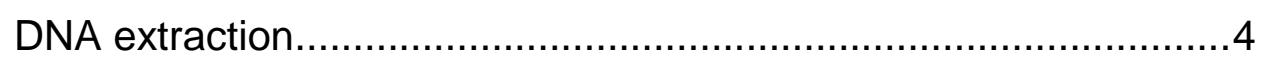

Amplification of target genes................................................. 5

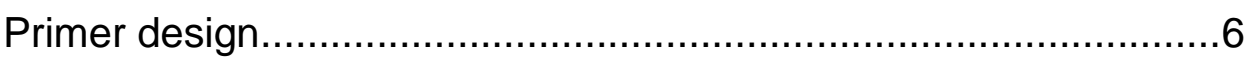

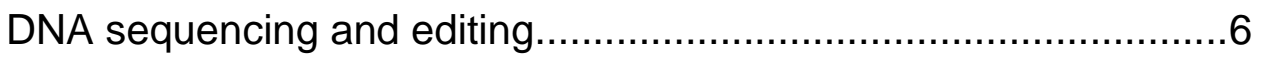

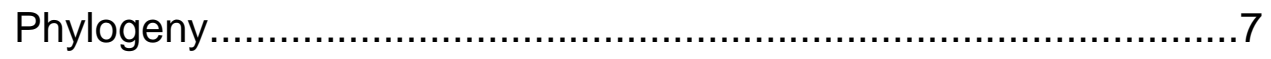

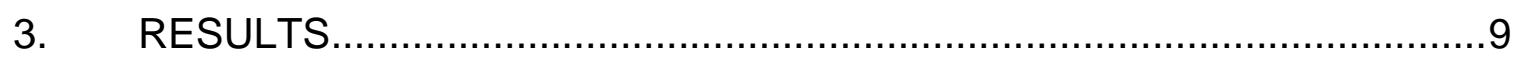

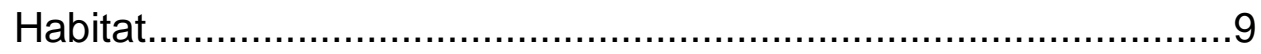

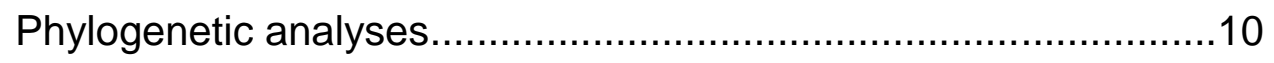

Haemopis ottae n. sp. description...........................................11 


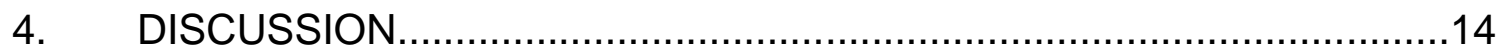

Haemopis ottae, habitat and behavior................................................14

North American terrestrial leeches..................................................14

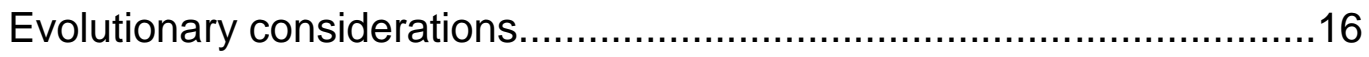

Speciation based on molecular clock values.........................................17

Evolution and dispersal of North American terrestrial leeches................17

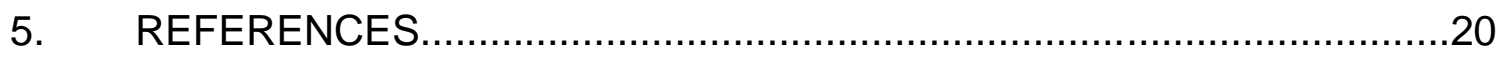

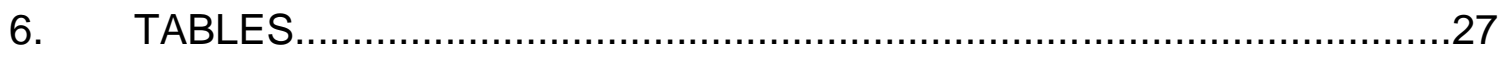

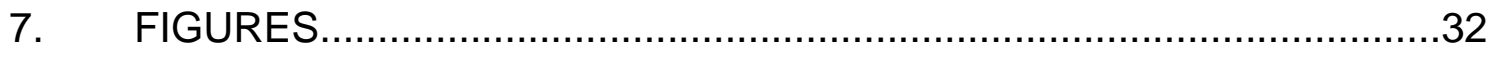




\section{LIST OF TABLES}

Table 1. Primer sequences used in polymerase chain reaction........................27

Table 2. Accession numbers used in phylogenetic analyses of haemopid

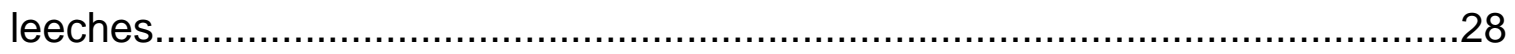

Table 3. Percent similarity values of cytochrome $c$ oxidase gene fragment, based

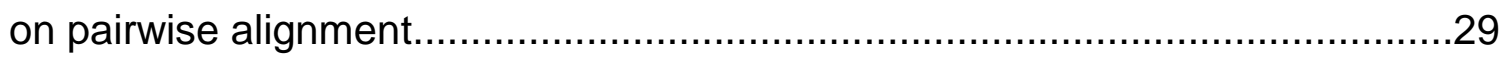

Table 4. Comparison of morphological traits of North American terrestrial

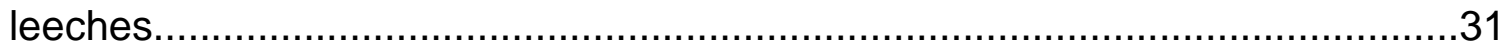




\section{LIST OF FIGURES}

Figure 1. Photograph of dissected Haemopis terrestris specimen....................32

Figure 2. Photograph of dissected Haemopis ottae specimen..........................34

Figure 3. Alignment used to design Haemopis specific $\mathrm{COI}$ primers...................36

Figure 4. Distribution of NJ Haemopis populations........................................40

Figure 5. Photographs of the Winslow field site ...........................................42

Figure 6. Fallen log at Winslow field site from which a Haemopis ottae specimen

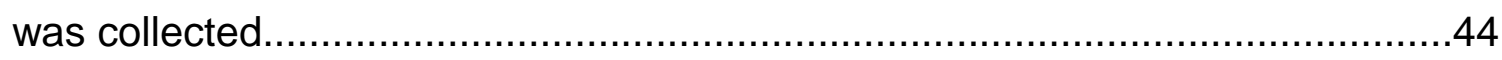

Figure 7. Phylogenetic tree of the combined data set resolving relationships

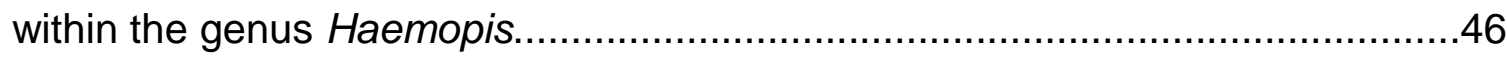

Figure 8. Most parsimonious tree obtained from cytochrome $c$ oxidase mtDNA,

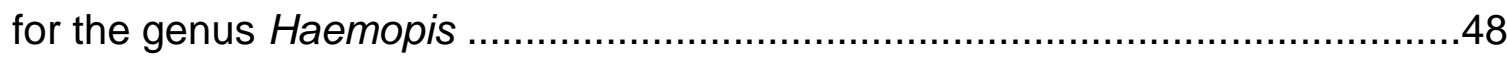

Figure 9. Most parsimonious tree obtained from 12S rDNA, for the genus

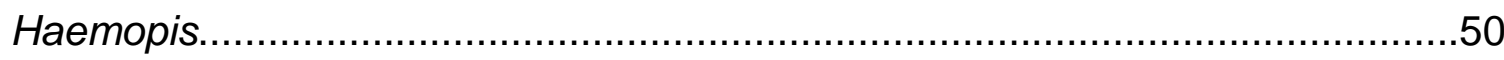

Figure 10. Most parsimonious tree obtained from 128S rDNA, for the genus

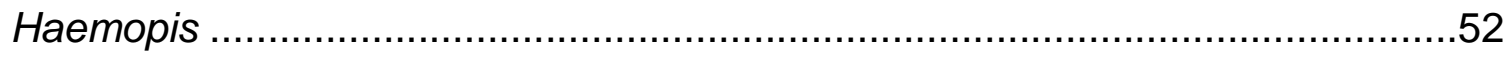

Figure 11. Photograph of live Haemopis ottae ...........................................54

Figure 12. Sketches of exterior morphology made from dorsal and ventral views

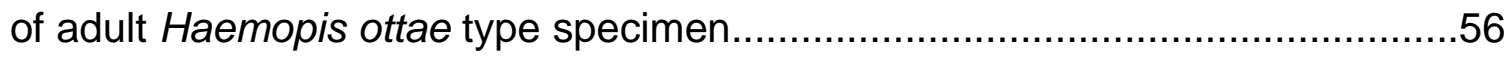

Figure 13. Sketches made from dorsal view of reproductive structures..............58 Figure 14. Map depicting the putative evolutionary history of terrestrial leeches in North America. 


\section{Introduction}

Leeches are a diverse order of Oligocheata comprising 650 known species (Siddall et al., 2006); collectively, they display remarkable biodiversity thriving in every continent except Antarctica. In contrast to the common perception of blood-feeding behavior (i.e., sanguivory), many leeches have adopted a predaceous feeding method, preying on soft-bodied animals such as earthworms and snails. The majority of leeches occur in freshwater habitatsindicative of their general susceptibility to desiccation--but a small number of terrestrial leeches are known worldwide, mostly from tropical or sub-tropical rainforests. These include members of the families Haemopidae, Cylicobdellidae and Americobdellidae as well as the African genus Semiscoloides (Borda et al., 2008). Only two North American terrestrial leeches, Haemopis terrestris (Forbes, 1890) and Haemopis septagon (Sawyer and Shelley, 1976; Shelley et al., 1979), are described, occurring in drier, temperate climates compared with other terrestrial species.

Haemopids are among the largest leeches in the world $(>30 \mathrm{~cm}$ for some species), and are grouped in the same suborder (Arhynchobdellida) as Hirudo medicinalis and Hirudo verbana, which have numerous research and medical applications (e.g., source of anti-thrombin blood thinners, oxygenating peripheral tissue in reconstructive surgeries; Markwardt, 2002; Knobloch et al., 2007). The genus Haemopis spans two continents (i.e., Europe, North America) but the 
majority of described species reside in North America, particularly in northern latitudes (Klemm, 1982). With the exception of $H$. terrestris and $H$. septagon, other species in the genus, namely Haemopis grandis Verrill 1874, Haemopis marmorata Moore 1912, Haemopis kingi Mathers 1952 and Haemopis lateromaculata Mathers 1963, are aquatic freshwater leeches most prevalent in Canada and the northern half of the continental United States. Maloney and Chandler (1976) explain this apparent geographical restriction by correlating higher levels of dissolved oxygen with cold water; note that species of Haemopis are relatively large thus decreasing their surface area/volume ratio and increasing oxygen demand. In contrast, the two described North American terrestrial leeches occur in southern and midwestern $(H$. terrestris) or southeastern ( $H$. septagon) states.

Several years ago, we received a specimen of Haemopis collected near a local resident's garden in southern New Jersey that did not match the characters of other Haemopis species. Subsequent fieldwork identified two additional populations in NJ. Our collective morphological and phylogenetic analyses suggest that these populations represent a third species of terrestrial leech in North America, and that terrestrialism occurred only once from a northern, aquatic ancestor from which the three terrestrial Haemopis lineages were derived. 


\section{Materials and methods}

Specimen collection and maintenance

Haemopis specimens collected throughout New Jersey were transported to Rutgers University (Camden, $\mathrm{NJ}$ ) and maintained in separate aquaria based on collection location. Aquaria contained $1-2 \mathrm{~cm} 0.3 \%$ Instant Ocean (Aquarium Systems) and were elevated $\sim 2 \mathrm{~cm}$ at one end to create a terrestrial to aquatic continuum. Leeches were fed one adult earthworm (e.g., Eisenia fetida) per week (found in the field or purchased from local pet stores), and typically survived $2+$ years in the laboratory. In addition, 16 live specimens identified as Haemopis terrestris were mailed to Rutgers University after being collected in Belton, Missourri.

\section{Dissections}

Specimens were fixed in $70 \%$ ethanol. External traits of live specimens were observed under a stereomicroscope (Miji EMZ-TR, Meiji Techno Co. Ltd.). Preserved specimens were dissected dorsally and ventrally, with representative sketches of internal morphology derived directly from type specimens. The type specimen is deposited in The Smithsonian Institution collection (Washington, D.C.) and the American Museum of Natural History (New York, NY) received a paratype. 
Dissections were performed primarily at Rutgers University, but several representative specimens of Haemopis terrestris from MO, Haemopis marmorata-like specimens collected in Camden, and the putative new species from NJ were dissected at the Smithsonian Institution with William Moser. Photographs of dissected Haemopis terrestris (Fig. 1) and the new species from NJ (Fig. 2) were taken for comparison.

\section{DNA extraction}

Tissue samples from live specimens were obtained by placing the leech in a $10 \%$ ethanol sedating solution until it was unresponsive to touch.

Approximately half of the caudal sucker was removed with a scalpel, and tissue cuttings were immediately processed using the E.Z.N.A. ${ }^{\mathrm{TM}}$ Tissue DNA kit (Omega Bio-tek) following the manufacturer's instructions. Leeches were maintained in $2 \%$ streptomycin for $\sim 72 \mathrm{~h}$ before returning to aquaria. Whenever possible, tissue from postmortem specimens was taken from the caudal sucker, in order to avoid contamination from gut contents. Genomic DNA was extracted by solubilizing tissue with Proteinase K, as described (Sambrook and Russell, 2001). To remove residual pigment (which blocked downstream applications), DNA was cleaned with the PowerClean ${ }^{\mathrm{TM}}$ DNA Clean-Up kit (MO BIO Laboratories, Inc.) according to the manufacturer's instructions. 
Amplification of target genes

Nuclear $12 \mathrm{~S}$ and $28 \mathrm{~S}$ ribosomal RNA (rRNA) and mitochondrial cytochrome $c$ oxidase subunit $1(\mathrm{COI})$ gene fragments were amplified from genomic DNA using the polymerase chain reaction (PCR). All 12S sequences were obtained at the American Museum of Natural History laboratory under the conditions described by Borda and Siddall (2004). For 28S rRNA, universal primers LROR (ACCCGCTGAACTTAAGC; Bunyard et. al. 1994) and LR5 (ATCCTGAGGGAAACTTC; Vilgalys and Hester 1990) were incorporated into PCR reactions generating a $\sim 1,060 \mathrm{bp}$ fragment. PCR conditions were $94^{\circ} \mathrm{C}$ for $30 \mathrm{sec}, 56^{\circ} \mathrm{C}$ for $1 \mathrm{~min}$, and $72^{\circ} \mathrm{C}$ for $1 \mathrm{~min}$, for 30 cycles with a final extension at $72^{\circ} \mathrm{C}$ for $10 \mathrm{~min}$. For COI, universal primers LCO (GGTCAACAAATCATAAAGATATTGG) and HCO (Folmer et al., 1994) often failed with this Haemopis species; consequently the leech-specific primer COI.4 (TCCTA(TC)AGGATCAAAAAAAGTAG) proximal to the HCO primer region was designed, and a $\sim 600 \mathrm{bp}$ COI fragment was successfully amplified from all individuals using an LCO/COI.4 primer set. COI PCR conditions were $94^{\circ} \mathrm{C}$ for 30 $\sec , 52^{\circ} \mathrm{C}$ for $1 \mathrm{~min}$, and $72^{\circ} \mathrm{C}$ for $1 \mathrm{~min}$, for 30 cycles, with final extension at $72^{\circ} \mathrm{C}$ for $10 \mathrm{~min}$. Reactions were performed under standard conditions using Titanium Taq DNA polymerase (ClonTech), supplemented with $1.5 \mathrm{mM} \mathrm{MgCl}_{2}$, in a Techne TC-312 Thermal Cycler. 


\section{Primer design}

Multiple attempts to amplify the $\mathrm{COI}$ gene using the universal primers were made. Despite altering primer, template and $\mathrm{MgCl}_{2}$ concentrations and annealing temperatures successful amplification using Haemopis DNA was not achieved. Leech specific COI primers were designed by creating a global alignment that included all Haemopis COI sequences deposited in GenBank and the $\mathrm{COI}$ sequence for Hirudo medicinalis (Fig.3). Two degenerate primers at the $5^{\prime}$ end and two degenerate primers at the 3 ' end of the sequence were designed using regions of high sequence identity.

An experiment was performed using the four newly designed primers and two universal primers in order to choose the optimal primer set for this genus. Although all primer combinations (except the universal primers) were successful in amplifying the target gene, the LCO/COI.4 set had the best result. The sequences of all primers used in these experiments are listed in Table 1.

\section{DNA sequencing and editing}

PCR products were excised from $1 \%$ agarose gels and prepared for sequencing using GeneClean (MP Biomedicals, LLC). DNA sequencing was conducted with forward and reverse primers by GeneWhiz Inc. (South Plainfield, $\mathrm{NJ}$ ), and at the American Museum of Natural History (New York, NY) as described in Borda and Siddall (2004). Sequences were manually adjusted in ChromasPro (Technelysium, Queensland, Australia) or BioEdit (Hall, 1999) and aligned with MUSCLE (Edgar, 2004) or CLUSTALW (Higgins et al., 1994). 
Accession numbers for $\mathrm{COI}, 12 \mathrm{~S}$ and $28 \mathrm{~S}$ sequences obtained from $\mathrm{NCBI}$ GenBank are listed in Table 2.

\section{Phylogeny}

Maximum parsimony analyses (MP) of combined COI, 12S, and 28S data, in addition to each individual gene, were performed in PAUP 4.06b10 (Swofford, 2000). Heuristic searches used 100 replicates of random addition sequences and tree-bisection-reconnection (TBR) branch swapping. Bremer support and clade support using non-parametric bootstrapping with 100 replicates was determined with the Willi Henning Society Edition of Tree analysis using New Technology (TNT; Goloboff et al., 2008). PAUP was used to determine retention and consistency indices ( $\mathrm{Rl}, \mathrm{Cl}$ respectively).

Bayesian Inference $(\mathrm{BI})$ analysis was performed on the combined data set in MrBayes v. 3.1 (Ronquist and Huelsenbeck, 2003). Data were partitioned for $12 \mathrm{~S}$ and 28S, and by codon position for COI. ModelTest (Posada and Crandall, 1998) via FindModel was used to determine the optimal model of evolution for each gene under the Akaike Information Criterion (AIC; Posada and Buckley, 2004). The general time reversible (GTR) model with a gamma distributed rate parameter was used for both $12 \mathrm{~S}$ and the $1^{\text {st }}, 2^{\text {nd }}$, and $3^{\text {rd }}$ codon positions of COI, and the HKY85 model with a gamma distributed rate parameter for the $28 \mathrm{~S}$ partition, yielding a total of five model-independent partitions. Two analyses were simultaneously run, with all parameter sets unlinked by partition for two million generations each, sampling every 200 generations, with a burn-in 
achieved by $<50,000$ generations. Setting the burn-in to 500,000 generations left a total of 15,002 trees sampled for assessment of posterior probabilities. Gaps were treated as missing data, and default settings were used for all other parameters. 


\section{Results}

Habitat

The species of Haemopis comprising the focus of this study was verified in three geographically distinct locations in New Jersey (Fig. 4). Winslow Township $\left(39^{\circ} 37^{\prime} 26.98^{\prime \prime} \mathrm{N}, 74^{\circ} 53^{\prime} 44.29^{\prime \prime} \mathrm{W}\right)$ was the northern-most location, Alloway $\left(39^{\circ} 33^{\prime} 58.23^{\prime \prime} \mathrm{N}, 75^{\circ} 20^{\prime} 6.82^{\prime \prime} \mathrm{W}\right)$ the western-most, and Pomona $\left(39^{\circ} 28^{\prime} 55.63^{\prime \prime} \mathrm{N}\right.$, $\left.74^{\circ} 31^{\prime} 58.80^{\prime \prime} \mathrm{W}\right)$ the most southeastern. All populations were separated by at least $34 \mathrm{~km}$. Ten specimens were collected in Alloway, three in Winslow, and one in Pomona. COI sequence comparisons revealed three haplotypes in total, one for each population (i.e., individuals within each population were genetically identical within the $\sim 600$ bp CO1 fragment); $12 S$ and $28 \mathrm{~S}$ sequences showed no sequence divergence between or within populations. Leeches were typically found in moist terrestrial environments, with cedar bogs proving the most prevalent habitat (Fig. 5), though some specimens were found several hundred meters from a water source. The most common micro-habitats were aquaticterrestrial transition zones (e.g., under leaf litter at the edge of streams, inside partially submerged logs)(Fig. 6). Water in these areas ranged from $\mathrm{pH}$ 4-5.

Additionally, Haemopis terrestris specimens sent from Missouri were reportedly found underneath a wood pile in a fully terrestrial environment. Specimens collected from Camden, which were morphologically similar to Haemopis marmorata, were found in a swampy transition zone at the edge of the Cooper River. 


\section{Phylogenetic analyses}

The combined COI, 12S, and 28S analysis contained 27 terminals with 2,921 aligned characters. Maximum parsimony of the combined data set (Fig. 7) yielded five equally parsimonious trees with 1,150 steps $(C l=0.753, R I=0.776)$, which differed only in the relative arrangement of individual isolates in Haemopis ottae n. sp. Bremer support for the node designating Hirudo medicinalis sister to the Haemopis genus was 20 , and that separating North American aquatic leeches from terrestrial leeches (Haemopis terrestris and Haemopis ottae n. sp.) was seven. The node supporting the Haemopis ottae n. sp. as a distinct species had a Bremer support value of 15 .

Analyses of the combined data set for MP and $\mathrm{BI}$ generated trees bearing identical topologies with all major clades having strong support, with one exception: the most parsimonious tree had Haemopis lateromaculata and Haemopis grandis as a sister clade to Haemopis marmorata, whereas the $\mathrm{BI}$ analysis put $H$. marmorata and $H$. lateromaculata as a sister clade to $H$. grandis (Fig. 7). Most parsimonious trees for COI (Fig. 8), 12S (Fig. 9), and the combined analyses (MP and $\mathrm{BI}$ ) contained all Haemopis ottae n. sp. specimens in a clade of their own, with the combined analysis tree having a bootstrap support of 100 and posterior probability of 1.00 . Only the most parsimonious for $28 \mathrm{~S}$ (Fig. 10) resulted in a polytomy with Haemopis terrestris.

With the exception of the above noted topology discrepancy, all other nodes had bootstrap values $\geq 89$ and posterior probability $\geq 0.95$. The genus 
Haemopis was clearly resolved as a monophyletic lineage, and European leeches (Haemopis sanguisuga and Haemopis caeca) were resolved from North American Haemopis sp. Haemopis terrestris was sister to Haemopis ottae n. sp. with strong branch support (bootstrap value $=95$, posterior probability $=1.00$ ). Both analyses strongly supported the monphyly of Haemopis ottae n. sp. as a distinct species, but its observed terrestrialism as a synapomorphy with $H$. terrestris. Putative $H$. marmorata specimens collected in NJ were sister to $H$. marmorata (GenBank; AY425380, AY425423, AF003270) supported by bootstrap values of 100 and posterior probability of 1.00 , suggesting a new cryptic species (Bely and Weisblat, 2006; Gustafsson et al., 2008).

Haemopis ottae n. sp.

Description: Adults up to $\sim 30 \mathrm{~cm}$ long and $\sim 3 \mathrm{~cm}$ wide. Dorsum pigmentation medium to dark brown with variable mid-dorsal stripe, moderate to extensive black mottling (Fig. 11). With classic Hirudinid arc eyespot pattern (Sawyer, 1986), containing five pairs bilateral eyespots. White-tipped papillae distributed bilaterally, wrapping around the periphery of dorsum and ventrum, absent in medial regions. First three sets of papillae on every third annulus, beginning at annulus with the posterior-most eyespots, every fifth annulus thereafter in mid-body segments ( 16 papillae were present per annulus), every other annulus in seven posterior-most annuli. Gonopores situated in furrow between annuli, separated by 7-7 1/2 annuli, female pore having a pronounced nipple-like appearance. Typical Haemopis body type evident (Fig. 12): wider 
posterior, firm muscular body, small caudal sucker characteristic of other terrestrial leeches (Sawyer and Shelly, 1976). Seventeen pairs of nephridiopores present in standard positions for Hirudinea (Fig. 11). Pharynx with 15 folds merging into three jaws, with $\sim 10$ distichodont teeth per jaw. Teeth color variable from translucent white to pale yellow. Male reproductive apparatus notably large and long, with thick muscular penis sheath terminating in a bulbous prostate (Fig. 13). Epididymis relatively large, more than twice size of pearlescent-sheened sperm sac (Figs. 2 \& 13a). Female reproductive system relatively uncoiled tubing, lacking a distinct vagina. Oviducts slightly coiled, terminating in oblong, bi-lobed ovaries.

\section{Remarks}

In addition to its apparent geographic isolation, $H$. ottae n. sp. has several morphological traits separating it from other North American terrestrial leeches. For example, $H$. ottae $\mathrm{n}$. sp. contains eight bilateral pairs of cirumferentially positioned, white-tipped papillae on every fifth annulus; similar structures are reported on $H$. marmorata but not $H$. terrestris or $H$. septagon. Also, $H$. ottae $n$. sp. lacks the lateral stripes present on both $H$. septagon and $H$. terrestris (Sawyer and Shelley, 1976; Shelley et al., 1979).

Internal reproductive structures among the three Haemopis terrestrial leeches are variable as well (Fig. 13). Specifically H. ottae n. sp. is characterized by a large epididymis more than twice the size of the sperm sac (Figs. $2 \& 13 a$ ), while the same structure in $H$. terrestris (Figs 1 \& 13c) and $H$. septagon is 
relatively small and does not extend much past the sperm sac. The vagina in $H$. ottae $\mathrm{n}$. sp. is significantly less pronounced and the vaginal duct is relatively straight when compared to $H$. terrestris or $H$. septagon. The number of teeth also varies, with $H$. ottae n. sp. having $\sim 10$ distichodont teeth, and $H$. terrestris and $H$. septagon having $\sim 15$. 


\section{Discussion}

Haemopis ottae, habitat and behavior

Based on morphological and genetic criteria, we formally propose the new species designation, Haemopis ottae, for the leech characterized in this studynamed after the Ott family who first reported this leech near Alloway, NJ. More remarkable than its status as one of the largest leeches in North America, $H$. ottae was discovered in the most densely populated state in the United States (albeit in a somewhat fragmented, rural setting). Regional COI comparisons showed that distinct populations within $\mathrm{NJ}$ displayed high sequence identity $(\geq 98.8 \%)$, indicating relatively recent geographical isolation; habitat fracturing caused by recent urbanization may account for low levels of divergence between populations. Haemopis ottae appears to be patchily distributed within its environment, often concentrated in only a small fraction of contiguous suitable habitat, and although northern NJ was thoroughly searched for specimens in comparable habitats, none were found or have been reported. Additional sampling throughout the east coast will help to determine whether current populations represent the leading edge of a northern or southern expansion, or whether $\mathrm{H}$. ottae is endemic to $\mathrm{NJ}$.

\section{North American terrestrial leeches}

Only two other species of terrestrial leech in North America, Haemopis terrestris and Haemopis septagon, are described. Haemopis terrestris occurs 
from the Great Lakes region to the Gulf Coast states (including Florida), and as far west as Colorado (Klemm, 1982). Interestingly, no reports of $H$. terrestris have surfaced east of the Appalachian Mountains since its original description (Forbes, 1890), suggesting a significant geologic and/or climatic barrier (see below). The other known North American terrestrial leech, $H$. septagon, appears restricted to southeastern states, namely the Carolinas and the southern part of Virginia (Sawyer and Shelley, 1976; Shelley et al., 1979), and has not been sighted in over 30 years (T. Shelly, personal communication). To date, $H$. ottae has only been collected in southern NJ.

The habitat preference for these three terrestrial Haemopis species is similar, undoubtedly related to their common diet of earthworms and snails. Haemopis terrestris, however, is often found many kilometers from a water source; this does not appear to be the case for $H$. septagon and $H$. ottae, which are more typically observed near swampy or wetland areas. Nevertheless, the Alloway, $\mathrm{NJ}$ field site at which $\mathrm{H}$. ottae was first collected contains a transient spring river bed that dries each summer, thus $H$. ottae can survive at least a few months each year in dry conditions. Under laboratory conditions, both $\mathrm{H}$. terrestris and $\mathrm{H}$. ottae displayed a preference for a terrestrial habitat in their sloped aquarium chambers, though they were regularly observed at the "landwater" interface and occasionally submerged in water. All three Haemopis species are good swimmers suggesting a common aquatic ancestry, and all have small posterior suckers consistent with terrestrialism. 


\section{Evolutionary considerations}

Both MP and BI analyses yielded trees with virtually identical topologies and very strong support at every branch, with the exception of the relationship between $H$. marmorata, $H$. lateromaculata, and $H$. grandis (Fig. 7). The cladogram from the combined data set of two nuclear genes (12S and 28S) and mitochondrial $\mathrm{COI}$ strongly corroborates $\mathrm{H}$. ottae as a previously undescribed haemopid species, and further resolves other ambiguous relationships within the genus Haemopis. For example, the monophyly of Haemopis is strongly supported and the tree topology agrees with higher level taxonomic analyses (Borda and Siddall, 2004a; Borda and Siddall, 2004b; Apakupakul et al., 1999). Current geographical distributions of haemopids are concurrent with the tree topology, with strong branch support separating the North American and European clades, suggesting a Laurasian ancestry. High boot-strap values and posterior probabilities for the branch separating $H$. terrestris and $H$. ottae from aquatic Haemopis leeches $(H$. grandis, $H$. lateromaculata, $H$. marmorata, $H$. kingl) further supports terrestrialism as a synapomorphy within the genus. Bremer supports for these branches reveal that an additional 14 steps would be needed to induce a polytomy, and merging $H$. terrestris with $H$. ottae would require 38 additional steps.

Interestingly, we collected Haemopis specimens from one field site (Camden, NJ) in our study that were morphologically indistinguishable from $\mathrm{H}$. marmorata but are well supported as sister to that clade, indicating a new cryptic species; similar evolutionary patterns have been detected in other oligochaete 
groups including Tubifex tubifex, Lumbriculus variegatus, and species of Helobdella and Hirudo (Erséus and Bergfeldt, 2007; Bely and Weisblat, 2006; Siddall et al., 2007; Gustaffson et al., 2008; Erséus and Gustaffson, 2009).

Speciation based on molecular clock values

To estimate an evolutionary time frame for the described speciation events, COI molecular clock variance values (Nagaraja, et al., 2004; Brower, 1994; Soto-Adames, 2002; Knowlton et al., 1993) were considered in the context of haemopid evolution. The observed $\sim 10 \% \mathrm{COI}$ sequence divergence between $H$. ottae and $H$. terrestris (Table 3 ) suggests that speciation occurred $\sim 10-20$ mya in the early-mid Miocene, while divergence from a putative aquatic ancestor occurred 30-40 mya. Both phylogenetic and morphological analyses argue for a single terrestrialism event among North American leeches, and subsequent divergence concomitant with continental colonization. The current distribution of aquatic haemopid leeches (Klemm, 1982) shows the greatest diversity in temperate higher latitudes, suggesting a deeply rooted ancestry in this region and the likely aquatic stock from which terrestrial haemopids arose.

Evolution and dispersal of North American terrestrial leeches

After transitioning onto land, the ancestral terrestrial lineage was likely forced south in response to multiple ice ages that occurred throughout the Quaternary. With the Appalachian Mountains acting as a natural barrier to EastWest gene flow, terrestrial leeches moving southwest probably formed the $H$. 
terrestris lineage, continuing their southern migration until reaching the Gulf Coast. The range of $H$. terrestris extends throughout the Gulf Coast states (including FL), thus allowing a putative northeastern migration up the Atlantic coast and into the Carolinas before speciating to form $H$. septagon. This lineage probably continued northward, with $\mathrm{H}$. ottae currently representing the leading edge of a northern expansion (Fig. 14). This pattern also suggests a primarily active mechanism of dispersal (i.e., crawling) since active transport (e.g., birds; Davies et al., 1982; Edward and Bohlen, 1996) should have permitted colonization of $H$. terrestris, $H$. septagon and $H$. ottae on either side of the Appalachian range. Morphological criteria arguably favor $H$. septagon as an intermediate species between $H$. terrestris and $H$. ottae; specifically, the distance between gonopores (7-7 1/2), presence of dorsal mottling, and similar size ratio of sperm sac/epididymis allies $H$. septagon with $H$. ottae, while $H$. septagon shares long, convoluted vaginal ducts and the presence of lateral stripes with $H$. terrestris (Table 4). Further, descriptions by Shelley and Sawyer (1976) note that some $H$. septagon specimens lacked lateral stripes, suggesting that trait is being lost.

Another plausible evolutionary scenario involves a split between eastern and western Haemopis lineages north of the Appalachian range, with the western branch defining $H$. terrestris and the eastern branch giving rise to $H$. ottae and $H$. septagon, the latter defining the leading edge of a putative southern expansion. Our genetic data cannot rule out this evolutionary pattern, but the consideration of morphological traits proves more problematic (e.g., lateral stripes, reproductive 
structures ally $H$. septagon with $H$. terrestris). Alternatively, a single passive dispersal event across the mid-Appalachian range could have given rise to a terrestrial Haemopis population closely related to $H$. terrestris, either $H$. ottae or H. septagon, but available evidence cannot distinguish this scenario from those proposed above. Clearly, the collection and analysis of additional Haemopis specimens throughout Canada and the continental United States will refine the details of the phylogeographic patterns that led to the current distribution of terrestrial leeches in North America. 


\section{References}

Apakupakul, K., Siddall, M.E., Burreson, E. M. 1999. Higher level relationships of leeches (Annelida: Clitellata: Euhirudinea) based on morphology and gene sequences. Mol. Phylogenet. Evol. 12, 350-359.

Bely, A.E., Weisblat, D.A. 2006. Lessons from leeches: a call for DNA barcoding in the Lab. Evol. Dev. 8, 491-501.

Borda, E., Oceguera-Figueroa, A., Siddall, M.E. 2008. On the classification, evolution and biogeography of terrestrial haemadipsoid leeches (Hirudinida: Arhynchobdellida: Hirudiniformes). Mol. Phylogenet. Evol. 46, 142-154.

Borda, E., Siddall, M.E. 2004. Arhynchobdellida (Annelida: Oligocheata: Hirudinida): phylogenetic relationships and evolution. Mol. Phylogenet. Evol. 30, 213-225.

Borda, E., Siddall, M.E. 2004. Review of the evolution of life history strategies and phylogeny of the Hirudinida (Annelida: Oligocheata). Lauterbornia 52, 5-25.

Brower, A.V.Z., 1994. Rapid morphological radiation and convergence among races of the butterfly Heliconius erato inferred from patterns of mitochondrial DNA evolution. Proc. Natl. Acad. Sci. USA 91, 6491-6495. 
Bunyard, B.A., Nicholson, M.S., Royse, D.J. 1994. A systematic assessment of Morchella using RFLP analysis of the 28S rRNA gene. Mycologia 86, 762-772.

Davies, R.W., Linton, L.R., Wrona, F.J. 1982. Passive dispersal of Four Species of Freshwater Leeches (Hirudinoidea) by ducks. Freshwater Invertebrate Biol. 1 (4) 40-44.

Edgar, R.C. 2004. MUSCLE: a multiple sequence alignment method with reduced time and space complexity. BMC Bioinformatics 5, 113.

Edwards, C.A., Bohlen, P.J. 1996. The biology and ecology of earthworms. Chapman and Hall, London.

Erséus, C., Bergfeldt, U. 2007. Six new species of the gutless genus Olavius (Annelida, Clitellata, Tubificidae). J. Mar. Biolog. Assoc. U.K.

Erséus, C., Gustaffson, D., 2009. Cryptic Speciation in Clitellate Model Organisms. In: Annelids in Modern Biology (Shain, D.H., Ed.), pp. 31-46, WileyBlackwell, Hoboken, NJ.

Folmer, O., Black, M. Hoeh, W., Lutz, R., Vrijenhoek, R. 1994. DNA primers for amplification of mitochondrial cytochrome $c$ oxidase subunit I from diverse metazoan invertebrates. Mol. Mar. Biol. Biotechnol. 3, 294-299. 
Forbes, S.A., 1890. An American terrestrial leech. Bulletin of the Illinios State Laboratory of Natural History. 3, 119-122.

Goloboff, P.A., Farris, J.S., Nixon, K.C. 2008. TNT, a free program for phylogenetic analysis. Cladisitics 24, 774-786.

Gustafsson, D.R., Price, D.A., Erseus, C. 2008. Genetic variation in the popular lab worm Lumbriculus variegatus (Annelida: Clitellata: Lumbriculidae) reveals cryptic speciation. Mol. Phylogenet. Evol.

Hall, T.A., 1999. BioEdit: a user-friendly biological sequence alignment editor and analysis program for Windows 95/98/NT. Nucl. Acids. Symp. Ser. 41, 95-98.

Hewitt, G.M. 2004. Genetic consequences of climatic oscillations in the Quaternary. Phil. Trans. R. Soc. Lond. 359, 183-195.

Higgins, D., Thompson, J., Gibson, T., Thompson, J.D., Higgins, D.G., Gibson, T.J. 1994. CLUSTAL W: improving the sensitivity of progressive multiple sequence alignment through sequence weighting, position-specific gap penalties and weight matrix choice. Nucleic Acids Research 22, 4673-4680. 
Klemm, D.J. 1982. A Guide to the Freshwater Annelida (Polychaeta, Naidid, and Tubificid Oligochaeta, and Hirudinea) of North America. Kendall/Hunt Publishing Co. Dubuque, lowa.

Knobloch, K., Gohritz, A., Busch, K., Spies, M., Vogt, P.M. 2007. Hirudo medicinalis - leech applications in plastic and reconstructive microsurgery - a literature review. Handchir. Mikrochir. Plast. Chir. 39(2), 103-107. Review. German.

Knowlton, N., Weigt, L.A., Solóranzo, L.A, Mills, D.K., Bermingham, E. 1993. Divergence in proteins, mitochondrial DNA, and reproductive compatibility across the isthmus of Panama. Science 260, 1629-1632.

Larkin, M.A., Blackshields, G., Brown, N.P., Chenna, R., McGettigan, P.A., McWilliam, H., Valentin, F., Wallace, I.M., Wilm, A., Lopez, R., Thompson, J.D., Gibson, T.J, Higgins, D.G. 2007. ClustalW and ClustalX version 2. Bioinformatics 23(21), 2947-2948.

Maloney, S.D., Chandler, C.M. 1976. Leeches (Hirudinea) in the Upper Stones River Drainage of Middle Tennessee. Am. Midl. Nat. 95(1), 42-48.

Markwardt, F. 2002. Hirudin as alternative anticoagulant - a historical review. Semin. Thromb. Hemost. 5, 405-515. Review. 
Mathers, C.K. 1954. Haemopis kingi, New Species (Annelida, Hirudinea). Am. Midl. Nat. 52(2), 460-468.

Mathers, C.K. 1963. Haemopis latero-maculatum, new species (Annelida: Hirudinea). Am. Midl. Nat. 70, 168-174.

Moore, P.J. 1912. Classification of the leeches of Minnesota. Geol. Nat. Hist. Survey Minn. Zool. Ser. No.5, Pt.3, pp.110-120.

Nagaraja, Nagaraju, J., Ranganath, H.A. 2004. Molecular phylogeny of the nasuta subgroup of Drosophila based on 12S rRNA, 16S rRNA and Col mitochondrial genes, RAPD and ISSR polymorphisms. Genes Genet. Syst. 79, 293-299.

Posada, D., Buckley, T.R. 2004. Model selection and model averaging in phylogenetics: advantages of Akaike Information Criterion and Bayesian approaches over likelihood ratio tests. Syst. Biol. 53, 793-808.

Posada, D., Crandall, K.A. 1998. Modeltest: testing the model of DNA substitution. Bioinformatics 14, 817-818.

Ronquist, F., Huelsenbeck, J.P. (2003). MrBayes 3: Bayesian phylogenetic inference under mixed models. Bioinformatics 19, 1572-1574. 
Sambrook, J., Russell, D.W. 2001. Molecular Cloning: A Laboratory Manual. Cold Spring Harbor Laboratory Press, Cold Spring Harbor, New York.

Sawyer, R.T. 1972. North American freshwater leeches, exclusive of the Piscicolidae, with a key to all species. Illinois Biological Monographs 46, 1-154.

Sawyer, R.T 1986. Leech Biology and Behavior. Oxford University Press, New York.

Sawyer, R.T., Shelley R.M. 1976. New records and species of leeches (Annelida: Hirudinea) from North and South Carolina. J. Nat. Hist. 10, 65-97.

Shelley, R.M., Braswell, A.L., Stephan, D.L. 1979. Notes on the Natural History of the Terrestrial Leech, Haemopis septagon Sawyer and Shelley (Gnathobdella: Hirudinidae). Brimleyana 1, 129-133.

Siddall, M.E., Bely, A.E., Borda, E. 2006. Hirudinida. Chapter 9. In: Reproductive Biology and Phylogeny of Annelida. (Rouse, G. and Pliejel, F. Eds.), Science Publishers, Enfield, New Hampshire, pp. 393-429. 
Siddall, M.E., Trontelj, P., Utevsky, S.Y., Nkamany, M., Macdonald III, K.S. 2007. Diverse molecular data demonstrate that commercially available leeches are not Hirudo medicinalis. Proc. R. Soc. B 274, 1481-1487.

Soto-Adames, F.N. 2002. Molecular phylogeny of the Puerto Rican Lepidocyrtus and Pseudosinella (Hexapoda: Collembola), a validation of Yoshii's "color pattern species". Mol. Phylogenet. Evol. 25, 27-42.

Swofford, D.L. 2000. PAUP*. Phylogenetic Analysis Using Parsimony ( ${ }^{*}$ and other methods). Version 4. Sinauer Associates, Sunderland, Massachusetts.

Verrill, A.E. 1874. Synopsis of the North American fresh-water leeches. Rept. U.S. Comm. Fish. 26, 666-689.

Vilgalys, R., Hester, M. 1990. Rapid genetic identification and mapping of enzymatically amplified ribosomal DNA from several Cryptococcus species. J. Bacteriol. 172, 4238-4246. 
Table 1. Primer sequences used in phylogenetic analyses of haemopid leeches. 


\begin{tabular}{|c|c|c|c|}
\hline Gene & $\begin{array}{l}\text { Primer } \\
\text { Name }\end{array}$ & Primer Sequence $\left(5^{\prime} \rightarrow 3^{\prime}\right)$ & Reference \\
\hline \multicolumn{4}{|c|}{$\begin{array}{l}\text { Nuclear } \\
12 \mathrm{~s}\end{array}$} \\
\hline & $\mathrm{A} 1$ & AAACTAGGATTAGATACCCTATTAT & \\
\hline & B1 & AAGAGCGACGGGCGATGTGT & \\
\hline \multicolumn{4}{|l|}{$28 S$} \\
\hline & LROR & ACCCGCTGAACTTAAGC & $\begin{array}{l}\text { Bunyard et } \\
\text { al., } 1994\end{array}$ \\
\hline & LR5 & ATCCTGAGGGAAACTTC & $\begin{array}{l}\text { Vilgalys and } \\
\text { Hester } 1990\end{array}$ \\
\hline \multicolumn{4}{|c|}{$\begin{array}{l}\text { Mitochondrial } \\
\text { COI }\end{array}$} \\
\hline & $\mathrm{HCO}$ & TAAACTTCAGGGTGACCAAAAAATCA & $\begin{array}{l}\text { Folmer et } \\
\text { al., } 1994\end{array}$ \\
\hline & LCO & GGTCAACAAATCATAAAGATATTGG & $\begin{array}{l}\text { Folmer et } \\
\text { al., } 1994\end{array}$ \\
\hline & COI.1 & GC(TC)TGATCAGCTATA(TGC)TAGG & \\
\hline & COl.2 & ATTGAG(TC)(TC)(AG)(GT)C(CTA)CA(AG)CCTGG & \\
\hline & COI.3 & AAAAAAAGTAGTATTTAAT(CTA)CGATC & \\
\hline & COI.4 & TCCTA(TC)AGGATCAAAAAAAGTAG & \\
\hline
\end{tabular}


Table 2. Accession numbers used in phylogenetic analyses of haemopid leeches. 


\begin{tabular}{|c|c|c|c|}
\hline \multirow[t]{2}{*}{ Taxon } & \multicolumn{3}{|c|}{ GenBank accession No. } \\
\hline & $28 \mathrm{~S}$ & $12 S$ & $\mathrm{COI}$ \\
\hline \multicolumn{4}{|l|}{ Ingroup } \\
\hline Haemopis sanguisuga & AY425381 & AF099960 & AF462021 \\
\hline Haemopis ceaca & AY425376 & AY425419 & AY040702 \\
\hline Haemopis kingi & AY425378 & AY425421 & AY425448 \\
\hline Haemopis marmorata & AY425380 & AY425423 & AF003270 \\
\hline Haemopis lateromaculata & AY425379 & AY425422 & AF116028 \\
\hline Haemopis grandis & AY425377 & AY425420 & AY425447 \\
\hline Haemopis terrestris & EU100080.1 & AY786446.1 & AY786459.1 \\
\hline Haemopis terrestris (MO) & FJ897505 & $\mathrm{N} / \mathrm{A}$ & FJ897514 \\
\hline $\begin{array}{l}\text { Haemopis marmorata-like (Camden, } \\
\mathrm{NJ} \text { ) }\end{array}$ & FJ897504 & FJ897509 & FJ897515 \\
\hline Haemopis ottae (Alloway, NJ) & FJ897511 & FJ897507 & FJ897510 \\
\hline Haemopis ottae (Winslow, NJ) & FJ897506 & FJ897508 & FJ897512 \\
\hline Haemopis ottae (Pomona, NJ) & $N / A$ & $N / A$ & FJ897513 \\
\hline \multicolumn{4}{|l|}{ Outgroup } \\
\hline Mesobdella gemmata & EU100084.1 & AY425434.1 & EU100097.1 \\
\hline Aliolimnatis michaelseni & AY425388.1 & AY425429.1 & AF116029.1 \\
\hline Hirdo medicinalis & EU100079.1 & DQ097197.1 & EU100093.1 \\
\hline
\end{tabular}


Table 3. Percent similarity of cytochrome $c$ oxidase subunit 1 gene fragment based on pairwise alignment using MUSCLE. 


\begin{tabular}{|c|c|c|c|c|c|c|c|}
\hline & $\begin{array}{c}\text { Mesobdella } \\
\text { gemmata }\end{array}$ & $\begin{array}{c}\text { Aliolimnatis } \\
\text { michaelseni }\end{array}$ & $\begin{array}{c}\text { Hirdo } \\
\text { medicinalis }\end{array}$ & $\begin{array}{c}\text { Haemopis } \\
\text { sanguisuga }\end{array}$ & $\begin{array}{c}\text { Haemopis } \\
\text { ceaca }\end{array}$ & $\begin{array}{c}\text { Haemopis } \\
\text { kingi }\end{array}$ & $\begin{array}{c}\text { Haemopis } \\
\text { marmorata } \\
\text { NJ }\end{array}$ \\
\hline $\begin{array}{c}\text { Mesobdella } \\
\text { gemmata }\end{array}$ & $\sim$ & $76.8 \%$ & $76.6 \%$ & $78.9 \%$ & $79.1 \%$ & $76.8 \%$ & $74.9 \%$ \\
\hline $\begin{array}{c}\text { Aliolimnatis } \\
\text { michaelseni }\end{array}$ & $76.8 \%$ & $\sim$ & $81.2 \%$ & $81.4 \%$ & $80.5 \%$ & $80.3 \%$ & $78.0 \%$ \\
\hline $\begin{array}{c}\text { Hirdo } \\
\text { medicinalis }\end{array}$ & $76.6 \%$ & $81.2 \%$ & $\sim$ & $82.7 \%$ & $82.8 \%$ & $81.9 \%$ & $78.9 \%$ \\
\hline $\begin{array}{c}\text { Haemopis } \\
\text { sanguisuga }\end{array}$ & $78.9 \%$ & $81.4 \%$ & $82.7 \%$ & $\sim$ & $98.5 \%$ & $87.5 \%$ & $82.5 \%$ \\
\hline $\begin{array}{c}\text { Haemopis } \\
\text { ceaca }\end{array}$ & $79.1 \%$ & $80.5 \%$ & $82.8 \%$ & $98.5 \%$ & $\sim$ & $87.3 \%$ & $81.6 \%$ \\
\hline $\begin{array}{c}\text { Haemopis } \\
\text { kingi }\end{array}$ & $76.8 \%$ & $80.3 \%$ & $81.9 \%$ & $87.5 \%$ & $87.3 \%$ & $\sim$ & $84.3 \%$ \\
\hline $\begin{array}{c}\text { Haemopis } \\
\text { marmorata NJ }\end{array}$ & $74.9 \%$ & $78.0 \%$ & $78.9 \%$ & $82.5 \%$ & $81.6 \%$ & $84.3 \%$ & $\sim$ \\
\hline $\begin{array}{c}\text { Haemopis } \\
\text { marmorata }\end{array}$ & $75.0 \%$ & $77.3 \%$ & $77.7 \%$ & $82.3 \%$ & $81.2 \%$ & $82.3 \%$ & $91.8 \%$ \\
\hline $\begin{array}{c}\text { Haemopis } \\
\text { lateromaculata }\end{array}$ & $74.5 \%$ & $77.1 \%$ & $77.1 \%$ & $82.1 \%$ & $81.1 \%$ & $83.2 \%$ & $91.6 \%$ \\
\hline $\begin{array}{c}\text { Haemopis } \\
\text { grandis }\end{array}$ & $75.0 \%$ & $77.0 \%$ & $77.3 \%$ & $82.5 \%$ & $81.4 \%$ & $82.7 \%$ & $92.1 \%$ \\
\hline $\begin{array}{c}\text { Haemopis } \\
\text { terrestris }\end{array}$ & $77.7 \%$ & $80.2 \%$ & $80.7 \%$ & $88.2 \%$ & $87.5 \%$ & $87.3 \%$ & $82.3 \%$ \\
\hline $\begin{array}{c}\text { Haemopis } \\
\text { terrestris MO }\end{array}$ & $77.3 \%$ & $79.5 \%$ & $81.1 \%$ & $87.3 \%$ & $86.6 \%$ & $88.0 \%$ & $82.7 \%$ \\
\hline $\begin{array}{c}\text { Haemopis } \\
\text { ottae-pomona }\end{array}$ & $77.1 \%$ & $81.2 \%$ & $82.1 \%$ & $88.4 \%$ & $87.8 \%$ & $87.8 \%$ & $83.2 \%$ \\
\hline $\begin{array}{c}\text { Haemopis } \\
\text { ottae-winslow }\end{array}$ & $77.5 \%$ & $81.9 \%$ & $82.5 \%$ & $88.7 \%$ & $88.5 \%$ & $87.8 \%$ & $83.7 \%$ \\
\hline $\begin{array}{c}\text { Haemopis } \\
\text { ottae-alloway }\end{array}$ & $77.3 \%$ & $81.8 \%$ & $82.5 \%$ & $88.9 \%$ & $88.7 \%$ & $87.8 \%$ & $83.7 \%$ \\
\hline
\end{tabular}


Table 3 continued

\begin{tabular}{|c|c|c|c|c|c|c|c|c|}
\hline & $\begin{array}{c}\text { Haemopis } \\
\text { marmorata }\end{array}$ & $\begin{array}{c}\text { Haemopis } \\
\text { lateromaculata }\end{array}$ & $\begin{array}{c}\text { Haemopis } \\
\text { grandis }\end{array}$ & $\begin{array}{c}\text { Haemopis } \\
\text { terrestris }\end{array}$ & $\begin{array}{c}\text { Haemopis } \\
\text { terrestris } \\
\text { MO }\end{array}$ & $\begin{array}{c}\text { Haemopis } \\
\text { ottae- } \\
\text { pomona }\end{array}$ & $\begin{array}{c}\text { Haemopis } \\
\text { ottae- } \\
\text { winslow }\end{array}$ & $\begin{array}{c}\text { Haemopis } \\
\text { ottae- } \\
\text { alloway }\end{array}$ \\
\hline $\begin{array}{c}\text { Mesobdella } \\
\text { gemmata }\end{array}$ & $75.0 \%$ & $74.5 \%$ & $75.0 \%$ & $77.7 \%$ & $77.3 \%$ & $77.1 \%$ & $77.5 \%$ & $77.3 \%$ \\
\hline $\begin{array}{c}\text { Aliolimnatis } \\
\text { michaelseni }\end{array}$ & $77.3 \%$ & $77.1 \%$ & $77.0 \%$ & $80.2 \%$ & $79.5 \%$ & $81.2 \%$ & $81.9 \%$ & $81.8 \%$ \\
\hline $\begin{array}{c}\text { Hirdo } \\
\text { medicinalis }\end{array}$ & $77.7 \%$ & $77.1 \%$ & $77.3 \%$ & $80.7 \%$ & $81.1 \%$ & $82.1 \%$ & $82.5 \%$ & $82.5 \%$ \\
\hline $\begin{array}{c}\text { Haemopis } \\
\text { sanguisuga }\end{array}$ & $82.3 \%$ & $82.1 \%$ & $82.5 \%$ & $88.2 \%$ & $87.3 \%$ & $88.4 \%$ & $88.7 \%$ & $88.9 \%$ \\
\hline $\begin{array}{c}\text { Haemopis } \\
\text { ceaca }\end{array}$ & $81.2 \%$ & $81.1 \%$ & $81.4 \%$ & $87.5 \%$ & $86.6 \%$ & $87.8 \%$ & $88.5 \%$ & $88.7 \%$ \\
\hline $\begin{array}{c}\text { Haemopis } \\
\text { kingi }\end{array}$ & $82.3 \%$ & $83.2 \%$ & $82.7 \%$ & $87.3 \%$ & $88.0 \%$ & $87.8 \%$ & $87.8 \%$ & $87.8 \%$ \\
\hline $\begin{array}{c}\text { Haemopis } \\
\text { marmorata NJ }\end{array}$ & $91.8 \%$ & $91.6 \%$ & $92.1 \%$ & $82.3 \%$ & $82.7 \%$ & $83.2 \%$ & $83.7 \%$ & $83.7 \%$ \\
\hline $\begin{array}{c}\text { Haemopis } \\
\text { marmorata }\end{array}$ & $\sim$ & $96.7 \%$ & $96.7 \%$ & $80.9 \%$ & $81.6 \%$ & $81.9 \%$ & $81.9 \%$ & $81.8 \%$ \\
\hline $\begin{array}{c}\text { Haemopis } \\
\text { lateromaculata }\end{array}$ & $96.7 \%$ & $\sim$ & $97.8 \%$ & $80.7 \%$ & $81.4 \%$ & $82.5 \%$ & $82.1 \%$ & $81.9 \%$ \\
\hline $\begin{array}{c}\text { Haemopis } \\
\text { grandis }\end{array}$ & $96.7 \%$ & $97.8 \%$ & $\sim$ & $81.2 \%$ & $81.4 \%$ & $82.3 \%$ & $81.9 \%$ & $81.8 \%$ \\
\hline $\begin{array}{c}\text { Haemopis } \\
\text { terrestris }\end{array}$ & $80.9 \%$ & $80.7 \%$ & $81.2 \%$ & $\sim$ & $97.8 \%$ & $90.5 \%$ & $90.3 \%$ & $90.1 \%$ \\
\hline $\begin{array}{c}\text { Haemopis } \\
\text { terrestris MO }\end{array}$ & $81.6 \%$ & $81.4 \%$ & $81.4 \%$ & $97.8 \%$ & $\sim$ & $90.3 \%$ & $90.1 \%$ & $90.0 \%$ \\
\hline $\begin{array}{c}\text { Haemopis } \\
\text { ottae-pomona }\end{array}$ & $81.9 \%$ & $82.5 \%$ & $82.3 \%$ & $90.5 \%$ & $90.3 \%$ & $\sim$ & $98.3 \%$ & $98.2 \%$ \\
\hline $\begin{array}{c}\text { Haemopis } \\
\text { ottae-winslow }\end{array}$ & $81.9 \%$ & $82.1 \%$ & $81.9 \%$ & $90.3 \%$ & $90.1 \%$ & $98.3 \%$ & $\sim$ & $99.8 \%$ \\
\hline $\begin{array}{c}\text { Haemopis } \\
\text { ottae-alloway }\end{array}$ & $81.8 \%$ & $81.9 \%$ & $81.8 \%$ & $90.1 \%$ & $90.0 \%$ & $98.2 \%$ & $99.8 \%$ & $\sim$ \\
\hline
\end{tabular}


Table 4. Comparison of morphological traits for the three North American terrestrial leeches. Green shading, traits that ally $H$. terrestris and $H$. septagon; yellow shading, traits that ally $H$. ottae and $H$. septagon; pink shading, traits unique to $H$. ottae. 


\begin{tabular}{|c|c|c|c|c|}
\hline Trait & H. terrestris & H. septagon & H. ottae & $\begin{array}{l}\text { Usable } \\
\text { traits }\end{array}$ \\
\hline $\begin{array}{l}\text { Coloring } \\
\text { (dorsal) }\end{array}$ & $\begin{array}{l}\text { Gray to black; no } \\
\text { mottling/spots }\end{array}$ & $\begin{array}{l}\text { Dark olive green; } \\
\text { numerous small } \\
\text { irregularly } \\
\text { scattered black } \\
\text { flecks }\end{array}$ & $\begin{array}{l}\text { Dark brown; } \\
\text { heavy black } \\
\text { mottling }\end{array}$ & No \\
\hline $\begin{array}{l}\text { Coloring } \\
\text { (ventral) }\end{array}$ & Lighter gray & $\begin{array}{l}\text { Lighter olive } \\
\text { green; no flecks }\end{array}$ & $\begin{array}{l}\text { Dark brown; no } \\
\text { mottling }\end{array}$ & No \\
\hline Coloring other & $\begin{array}{l}\text { Dark dorsal mid- } \\
\text { line; paler buff } \\
\text { marginal stripes; } \\
\text { dark ventral sub- } \\
\text { marginal stripe }\end{array}$ & $\begin{array}{l}\text { Dark strip along } \\
\text { dorsal mid-line; } \\
\text { yellow marginal } \\
\text { stripes }\end{array}$ & $\begin{array}{l}\text { Distinct black } \\
\text { dorsal mid-line }\end{array}$ & No \\
\hline Papillae & None & None mentioned & $\begin{array}{l}8 \text { present every } \\
5^{\text {th }} \text { annulus; white } \\
\text { tipped }\end{array}$ & Yes \\
\hline Size & $\begin{array}{l}7 \text { inches long; } 0.75 \\
\text { inches wide } \\
80-150 \mathrm{~mm} \text { long }\end{array}$ & $\begin{array}{l}69 \mathrm{~mm} \text { long; } \\
12 \mathrm{~mm} \text { wide } \\
165 \mathrm{~mm} \text { long; } \\
25 \mathrm{~mm} \text { wide }\end{array}$ & $\begin{array}{l}248 m m \text { long; } \\
28 \mathrm{~mm} \text { wide }\end{array}$ & Yes \\
\hline $\begin{array}{l}\text { Distance } \\
\text { between } \\
\text { gonopores } \\
\end{array}$ & $\begin{array}{l}5 \text {-5.5 annuli; on } \\
\text { annulus }\end{array}$ & $\begin{array}{l}6.5-7 \text { annuli; male } \\
\text { pore in furrow }\end{array}$ & $\begin{array}{l}7-7.5 \text { annuli; in } \\
\text { furrow }\end{array}$ & No \\
\hline Teeth (type) & Bicuspid & distichodont & $\begin{array}{l}\text { distichodont; } \\
\text { blunt }\end{array}$ & No \\
\hline Teeth (\#) & $12-15$ & 15 & 20 & No \\
\hline Eye spots & $\begin{array}{l}5 \text { pair - typical } \\
\text { hirudinid position }\end{array}$ & $\begin{array}{l}5 \text { pair - typical } \\
\text { hirudinid position }\end{array}$ & $\begin{array}{l}5 \text { pair - typical } \\
\text { hirudinid position }\end{array}$ & No \\
\hline \# testisacs & 10 pair & 11 pair & $8-12$ pair & No \\
\hline $\begin{array}{l}\text { Sperm } \\
\text { sac/epididymis }\end{array}$ & $\begin{array}{l}\text { Sperm sac smaller } \\
\text { compared to } \\
\text { epididymis; } \\
\text { epididymis does } \\
\text { not extend past ss; } \\
\text { ss narrow and } \\
\text { curved }\end{array}$ & $\begin{array}{l}\text { = to } 1.5 x ; \text { ss } \\
\text { straight; } \\
\text { epididymis } \\
\text { extends beyond ss }\end{array}$ & $\begin{array}{l}\text { More than } 2 x s \text { the } \\
\text { size of the } \\
\text { epididymis; } \\
\text { epididymis } \\
\text { extends far past } \\
\text { the ss }\end{array}$ & Yes \\
\hline Ovaries & $\begin{array}{l}\text { Moderately sized; } \\
\text { bi-lobed }\end{array}$ & $\begin{array}{l}\text { Small paired; bi- } \\
\text { lobed }\end{array}$ & Small; bi-lobed & Yes \\
\hline Vaginal duct & Long \& convoluted & Long \& convoluted & $\begin{array}{l}\text { Long \& relatively } \\
\text { straight }\end{array}$ & Yes \\
\hline vagina & $\begin{array}{l}\text { Large and wide; } \\
\text { tubular }\end{array}$ & Large \& tubular & Small \& tubular & Yes \\
\hline
\end{tabular}


Figure 1. Photograph of dissected Haemopis terrestris specimen. Magnified view of reproductive systems and pharynx (A). Dissection showing ventral cut and full size of specimen, including lateral stripe indicative of $H$. terrestris (B). Scale bar is $1.5 \mathrm{~cm}$. 

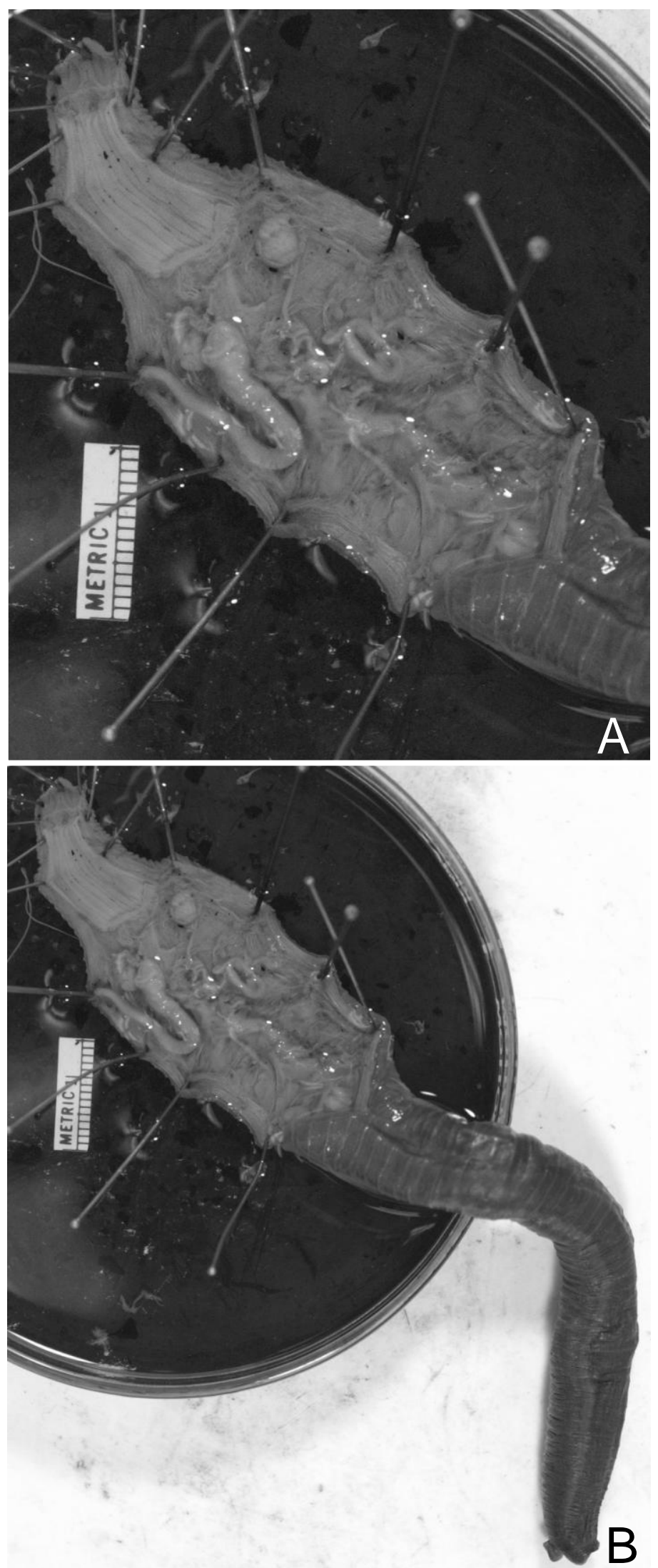
Figure 2. Photograph of dissected Haemopis ottae specimen. Magnified view of reproductive systems and pharynx $(A)$. Dissection showing ventral cut and full size of specimen (B). Scale bar is $1.5 \mathrm{~cm}$. 


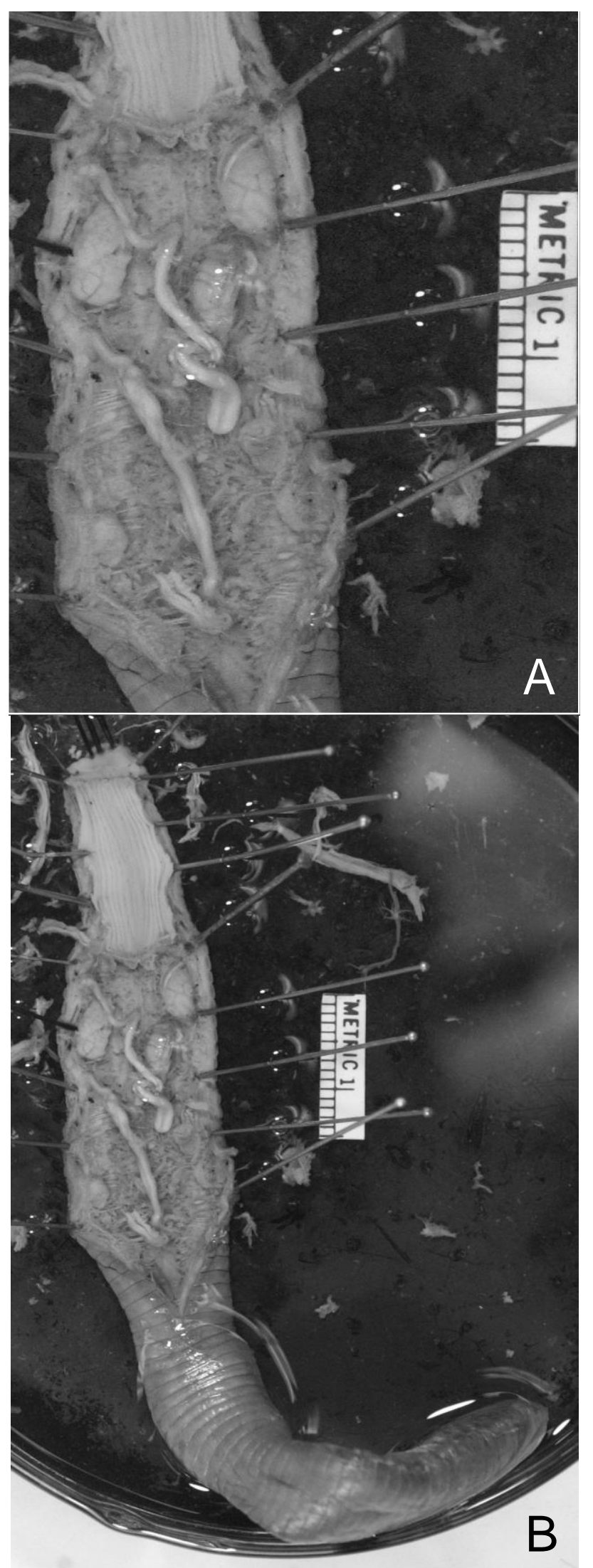


Figure 3. Alignment used to design Haemopis specific $\mathrm{CO}$ primers. Circled regions designate sequence used for primer design. Blue, COI.1; Red, COI.2; Yellow, COI.3; Green, COI.4. 
Haemopis terrestris Haemopis elegans Hirudo medicinalis Haemopis caeca Haemopis sanguisuga Haemopis kingi Haemopis grandis Haemopis lateromaculata Haemopis marmorata

Haemopis terrestris Haemopis elegans Hirudo medicinalis Haemopis caeca Haemopis sanguisuga Haemopis kingi Haemopis grandis Haemopis lateromaculata Haemopis marmorata

Haemopis terrestris Haemopis elegans Hirudo medicinalis Haemopis caeca Haemopis sanguisuga Haemopis kingi Haemopis grandis Haemopis lateromaculata Haemopis marmorata

Haemopis terrestris Haemopis elegans Hirudo medicinalis Haemopis caeca Haemopis sanguisuga Haemopis kingi Haemopis grandis Haemopis lateromaculata Haemopis marmorata

Haemopis terrestris Haemopis elegans Hirudo medicinalis Haemopis caeca Haemopis sanguisuga Haemopis kingi Haemopis grandis Haemopis lateromaculata Haemopis marmorata

Haemopis terrestris Haemopis elegans Hirudo medicinalis Haemopis caeca Haemopis sanguisuga Haemopis kingi Haemopis grandis Haemopis lateromaculata Haemopis marmorata
COI. 1

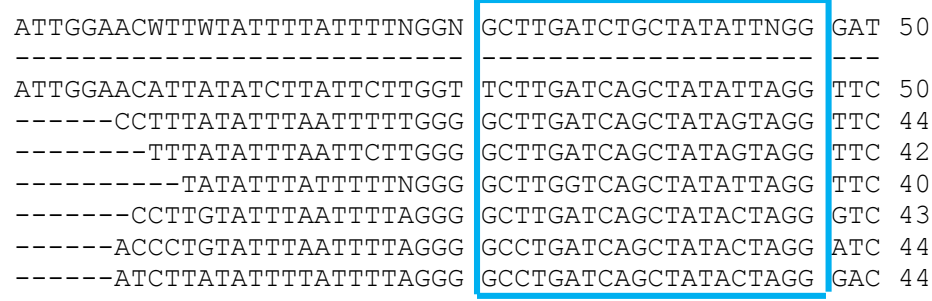

$\mathrm{COI} .2$

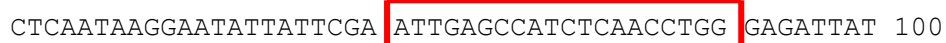
--------------TTCGT ATTGAGTTATCTCAACCTGG AGGACTTT 33 тTCтAтAAGATCAATTATTCGA AtTGAATtGgCACAACCTGg AAAgTTTT 100 ATCAATAAGAAGGATTATTCGA ATTGAATTGTCACAACCTGG AAGATTTT 94 ATCAATAAGAAgGATTATTCGA ATtGAATTATCACAACCTGG TAGATTTT 92 TTCTATAAGAACTATTATCCGA ATTGAATTGGCTCAACCTGG GAGATTTT 90 AtCCAtAAgtAgGATtATtCGA ATtgAgtTAgCTCAgCCTGg TAgGTtTC 93 ATCCATAAGTAGgATTATTCGA ATtGAgtTAGCCCAGCCTGG TAGGTTTC 94 AtCCAtAAgtAgGAtTAtTCGA ATtgAgtTAgCCCAGCCTGg TAgGtTTt 94

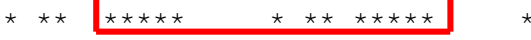

TAGGAAATGATCAATTATATAATTCATTAGTAACAGCTCATGGATTAATT 150 TAGGTAATGATCAATTATATAATTCATTAGTAACAGCTCATGGATTAATT 83 TGGGTGATGATCAACTATACAATTCTTTAGTAACTGCTCATGGATTAGTA 150 TAGGTAATGATCAATTATATAATTCATTAGTTACAGCTCATGGATTAATT 144 TAGGTAATGATCAATTATATAATTCATTAGTTACAGCTCATGGATTGATT 142 TAGGTAATGACCAATTGTATAATTCATTAGTTACAGCTCATGGATTAATT 140 TAGGTAACGACCAGTTATATAATTCATTAGTAACTGCTCATGGGTTGATC 143 TAGGTAACGACCAGTTATATAATTCATTAGTAACTGCTCATGGGTTGATC 144 TAGGTAATGATCAGTTATATAATTCATTAGTAACTGCTCATGGGTTGATC 144

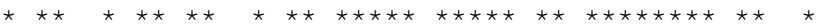

АтAАTTTCTTTATGGTTATGCCTATTTTGATTGGTGGGTTTGGTAATT 200 ATAATTTTTTTATAGTAATACCTATCTTAATTGGGGGATTTGGTAATTG 133 ATAATTTTCTTTATAGTAATACCAATTTTAATTGGTGGCTTTGGAAATTG 200 ATAATTTCTTTATAGTTATACCTATTTAAATGGAGGATTCGGAAATTG 194

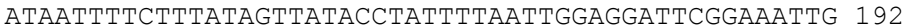

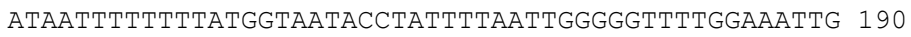
АтАAтстTTTTTATAGTGATACCCATTTTAATTGGGGGGTTTGGAAATTG 193 AтAAтстTтTTATAGTAATACCCATtTTAATTGGGGGGTTTGGAAATTG 194 ATAATстTTTTTATAGTAATACCCATtTTAATTGGGGGGTTTGGAAATTG 194

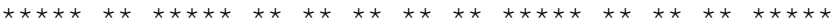

AтTACTACСTTTAATAATTGGAGCCCCTGATATAGCTTTTCCTCGATTAA 250 ATTGCTTCCATTAATAATTGGAGCTCCAGACATAGCTTTTCCTCGATTGA 183 AстTTTGCCATTAATAGTTGGTGCTATTGATATATCATTTCCCCGATTAA 250 ACTATTACCTTTAATAATTGGTGCTCCGGATATAGCATTCCCACGATTAA 244 АстАтTAССтTTAAтAATTGGTGCTCCGGATATAGCATTCCCACGATTAA 242 ATTATTACCTTTAATAATCGGAGCACCAGATATAGCATTTCCTCGATTAA 240 ATTACTCCCGTTAATAATCGGGGCACCCGATATGGCATTCCCACGGCTAA 243 ATTACTTCCGCTAATAATCGGGGCACCCGATATGGCATTCCCACGGCTAA 244 ATtACTCCCATtAATAATTGGgGCACCTGATATAGCATTCCCGCGGCTAA 244

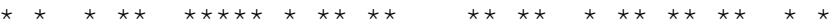

AтAАTTTAAgTTTTTGATTATTACCACCTTCATTAATTATATTGTTAAgA 300 ATAATTAAGATTTTATTATTACCTCCCTCTTTAATTATATTATTAAGA 233 ATAATTTTAGATTTTGGTTATTACCACCTTCAATAATTATATTATTAAGT 300 ATAATTTAAGATTTTGATTATTACCGCCTTCATTAATTATATTATTGAGA 294

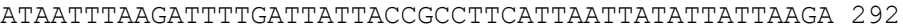
AтAACTTAAGGTTTTGATATTACCTCCTTCATTAATTATATTATTAAgT 290

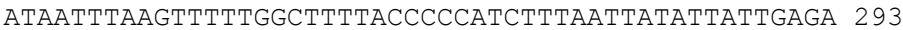
ATAATTAAGTTTTGGCTTTTACCTCCATCTTTAATTATATTATTGAGA 294 ATAATTTAATTTTTGGTTTTACCCTCATCTTTAATTATACTATTGAGA 294 
Haemopis terrestris Haemopis elegans Hirudo medicinalis Haemopis caeca Haemopis sanguisuga Haemopis kingi Haemopis grandis Haemopis lateromaculata Haemopis marmorata

Haemopis terrestris Haemopis elegans Hirudo medicinalis Haemopis caeca Haemopis sanguisuga Haemopis kingi Haemopis grandis Haemopis lateromaculata Haemopis marmorata

Haemopis terrestris Haemopis elegans Hirudo medicinalis Haemopis caeca Haemopis sanguisuga Haemopis kingi Haemopis grandis Haemopis lateromaculata Haemopis marmorata

Haemopis terrestris Haemopis elegans Hirudo medicinalis Haemopis caeca Haemopis sanguisuga Haemopis kingi Haemopis grandis Haemopis lateromaculata Haemopis marmorata

Haemopis terrestris Haemopis elegans Hirudo medicinalis Haemopis caeca Haemopis sanguisuga Haemopis kingi Haemopis grandis Haemopis lateromaculata Haemopis marmorata

Haemopis terrestris Haemopis elegans Hirudo medicinalis Haemopis caeca Haemopis sanguisuga Haemopis kingi Haemopis grandis Haemopis lateromaculata Haemopis marmorata
TCCTCTATTATTGAAAGAGGGGTAGGTACAGGTTGAACCTTATATCCTCC 350 TCCTCTATAATTGAGGGAGGAGTAGGTACAGGTTGAACATTATATCCTCC 283 TCATCAATAATCGAAAATGGGGTAGGTACAGGATGAACCCTTTATCCTCC 350 TCTTCTATAATTGAAGGAGGTGTTGGTACAGGTTGAACATTATATCCTCC 344 TCTTCTATAATTGAAGGAGGTGTTGGTACAGGTTGAACATTATATCCTCC 342 TCTTCTATTATTGAAGGAGGTGTTGGAACAGGGTGAACATTATACCCTCC 340 TCTTCTATTATTGAAGGGGGTGTTGGTACAGGTTGAACTCTATATCCTCC 343 TCTTCTATTATTGAAGGGGGTGTTGGTACAGGTTGAACTCTATACCCTCC 344 TCTTCTATTATTGAAGGGGGTGTTGGTACAGGTTGAACTCTATACCCTCC 344

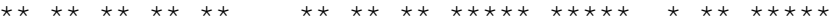

TTTAGCAGATAGATTATTTCATTCAGGTCCATCGGTAGATATAGCTATTT 400 ATTATCAGATAGTTTATTTCATTCAGGTCCTTCAGTTGATATAGCTATTT 333 TCTAGCAGATAGTATTTCTCATTCAGGCCCATCTGTAGATATGGCTATTT 400 TTTAGCAGATAATATATTTCATTCAGGACCTTCAGTAGATATAGCTATTT 394 TTTAGCAGATAATATATTTCATTCAGGACCTTCAGTAGATATAGCTATTT 392 TTTATCGGATAGATTATTTCATTCTGGGCCATCAATTGATATGGCCATTT 390 TTTATCAGATAGGTTGTTTCATTCAGGGCCGTCAGTAGATATGGCTATTT 393 TTTATCAGATAGGTTGTTTCATTCAGGGCCGTCAGTTGATATGGCTATTT 394 TTTATCAGATAGGCTGTTTCATTCAGGGCCGTCAGTTGATATGGCTATTT 394

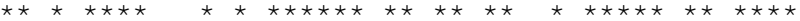

TTTCATTACATATAGCTGGAGCATCATCTATTTTAgGCTCATTAAACTTT 450 TTTCATTACATATAGCCGGAGCATCATCTATTTTAGGTTCATTGAATTTT 383 TTTCATTACATATAGCTGGGGCGTCATCAATTCTTGGATCTTTAAATTTT 450 TTTCATTACACATGGCTGGTGCATCATCTATTTTAGGTTCTTTAAATTTT 444 TTTCATTACACATGGCTGGAGCATCATCTATTTTAGGTTCTTTAAATTTT 442 TTTCATTACATATAGCAGGAGCTTCATCTATTTTGGGATCTTTAAATTTT 440 TTTCACTACATATAGCAGGAGCCTCGTCAATTTTAGGCTCTTTGAACTTT 443 TTTCACTACATATAGCAGGAGCCTCGTCAATTTTAGGTTCTTTGAACTTT 444 TTTCACTACATATAGCAGGAGCCTCGTCAATTTTAGGTTCTTTGAACTTT 444

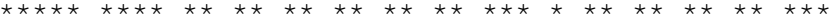

ATTTCTACAATTATTAATATACGAATTAAAGGTATAAGATCTGATCGAGT 500 ATTTCTACTATTATTAATATACGAATTAAAGGAATAAGATCTGAACGAGT 433 ATTTCAACTATTATTAATATACGTATTTCTGGAATAAGATCTGAACGAGT 500 ATTTCTACTATTATTAATATACGAATTAAAGGTATAAGGTCCGAACGAAT 494 ATTTCTACTATTATTAATATACGAATTAAAGGTATAAGGTCCGAGCGAGT 492 ATTTCTACAATTATTAATATACGAATTAAAGGTATAAGTTCTGAACGTGT 490 ATTTCGACAATTGTTAATATGCGAACCAAGGGGATAGGTTCTGAGCGAGT 493 ATTTCGACAATTGTTAATATGCGAACCAAGGGGATAGGTTCTGAGCGAGT 494 ATTTCGACAATTGTTAATATGCGAACCAAGGGGATAGGTTCTGAGCGAGT 494

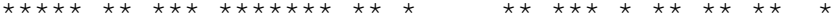

ACCTTTATTTGTATGATCAGTTGTTATTACAACAGTTCTGTTATTATTGT 550 TCCTTTATTTGTATGATCTGTTGTAATTACAACAGTGTTATTATTACTTT 483 TCCGCTATTTGTATGATCAGTAGTAATTACTACTATTTTATTGCTTCTTT 550 TCCTTTATTTGCTTGATCTGTTGTAATTACAACGGTTTTATTATTATTGT 544 TCCTTTATTTGTTTGATCTGTTGTAATTACAACGGTTTTATTATTATTGT 542 ACCTTTATTTGTATGATCAGTTGTAATTACTACAGTTTTATTACTGTTAT 540 ACCATTATTTGTATGGTCTGTTGTAATTACTACTATCCTACTACTTTTAT 543 ACCATTATTTGTATGGTCTGTTGTAATTACTACTATCCTATTACTTTTAT 544 ACCATTATTTGTATGGTCTGTTGTAATTACTACTATCCTACTACTTTTAT 544

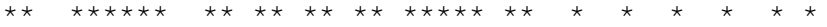

CTTTACCTGTTTTAGCTGCAGCTATTACTATATTATTAACA GATCGTAAT 600 CATTACCAGTATTAGCAGCTGCTATTACTATATTATTAACT GATCGTAAT 533 CATTACCAGTATTAGCTGCAGCTATTACAATATTATTAACT GATCGTAAT 600 CTTTACCAGTGTTAGCAGCAGCTATTACTATATTATTAACA GATCGAAAC 594 CTTTACCAGTGTTAGCAGCAGCTATTACTATATTATTAACA GATCGAAAC 592 CATTACCAGTTTTAGCTGCTGCTATTACTATATTATTAACA GATCGAAAT 590 CGTTACCGGTTTTGGCTGCAGCAATTACAATACTCTTGACA GATCGGAAC 593 CATTACCGGTTTTGGCTGCAGCAATTACAATACTCTTGACA GATCGGAAC 594 CGTTACCGGTTTTGGCTGCAGCAATTACAATACTCTTGACA GATCGGAAC 594

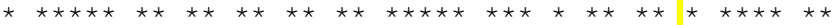


Haemopis terrestris

Haemopis elegans

Hirudo medicinalis

Haemopis caeca

Haemopis sanguisuga

Haemopis kingi

Haemopis grandis

Haemopis lateromaculata

Haemopis marmorata

Haemopis terrestris

Haemopis elegans

Hirudo medicinalis

Haemopis caeca

Haemopis sanguisuga

Haemopis kingi

Haemopis grandis

Haemopis lateromaculaa

Haemopis marmorata

\section{COI.3}

\section{COI.4}

TTAAATA CTACTTTTTT GATCCTATAGGA GGTGGAGATCCAGTATTGTT 650 TTAAATA CTACTTTTTTT GATCCTATAGGA GGAGGAGATCCAGTTTTATT 583

TTAAATA CTACTTTTTTT GATCCAATTGGA GGAGgGgATCCAGTCTTATT 650 TTAAATA CTACTTTTTTT GATCCTATAGGA GGTGGTGACCCAGTTTTATT 644

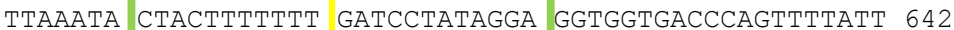
TTAAATA CTACTTTCTTT GATCCTGTAGGA GGAGGAGATCCAGTTTTATT 640 TTAAATA CTACTTTTTTT GATCCTGTAGGA GGGGGGGACCNTATTTTATT 643 TTAAATA CTACTTTTTTT GATCCTGTAGGA GGGGGAGATCCTATTTTATT 644

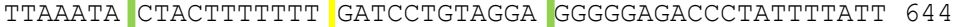

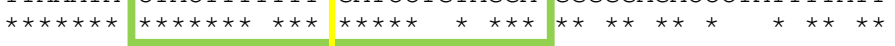

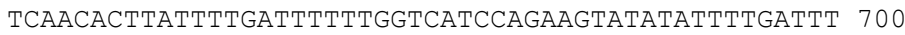

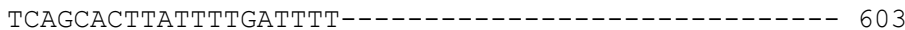
TCAACATCTATTTTGTTCTTTGgTCATCCAGAgGTTTATATTTTAATTT 700 TCAGC---------------------------------------- 649 TCAAC--------------------------------------------- 647 TCAGC------------------------------------------- 645

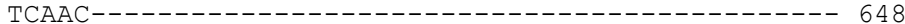
TCAACAC------------------------------------------- 651 TCAACTT---------------------------------------- 651

$\star \star \star \star *$ 
Figure 4. Distribution of New Jersey Haemopis populations. Shaded area represents land designated as New Jersey Pinelands. Distance between field sites indicated in $\mathrm{km}$. 


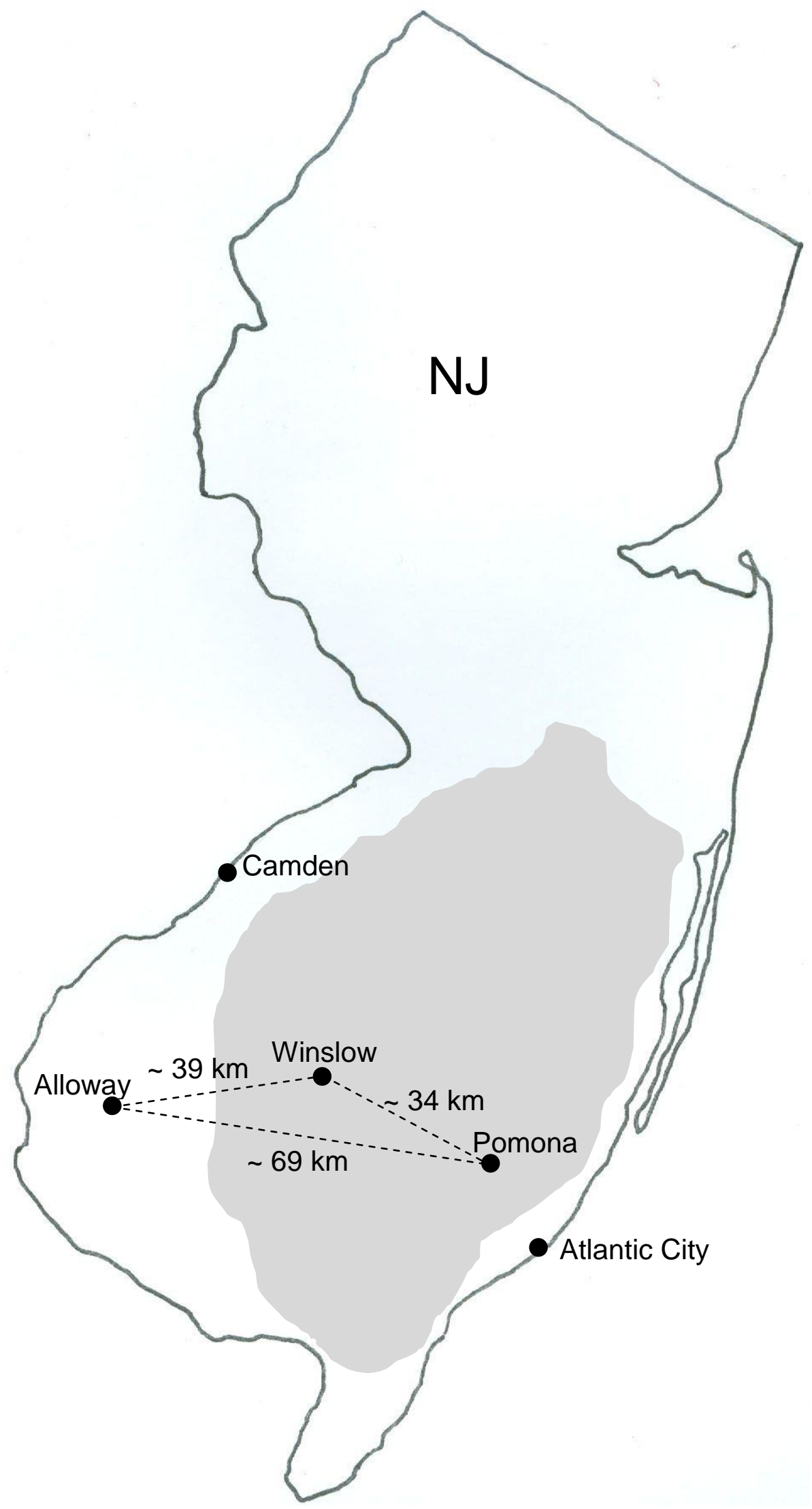


Figure 5. Photographs of the Winslow field site. Pictures are representative of the cedar bog habitat where Haemopis ottae is most commonly found. These areas have a high water table and are prone to flooding from adjacent streams (A). There is little undergrowth and habitat often contains Sphangum sp. moss, which only grows in low pH environments (B). 


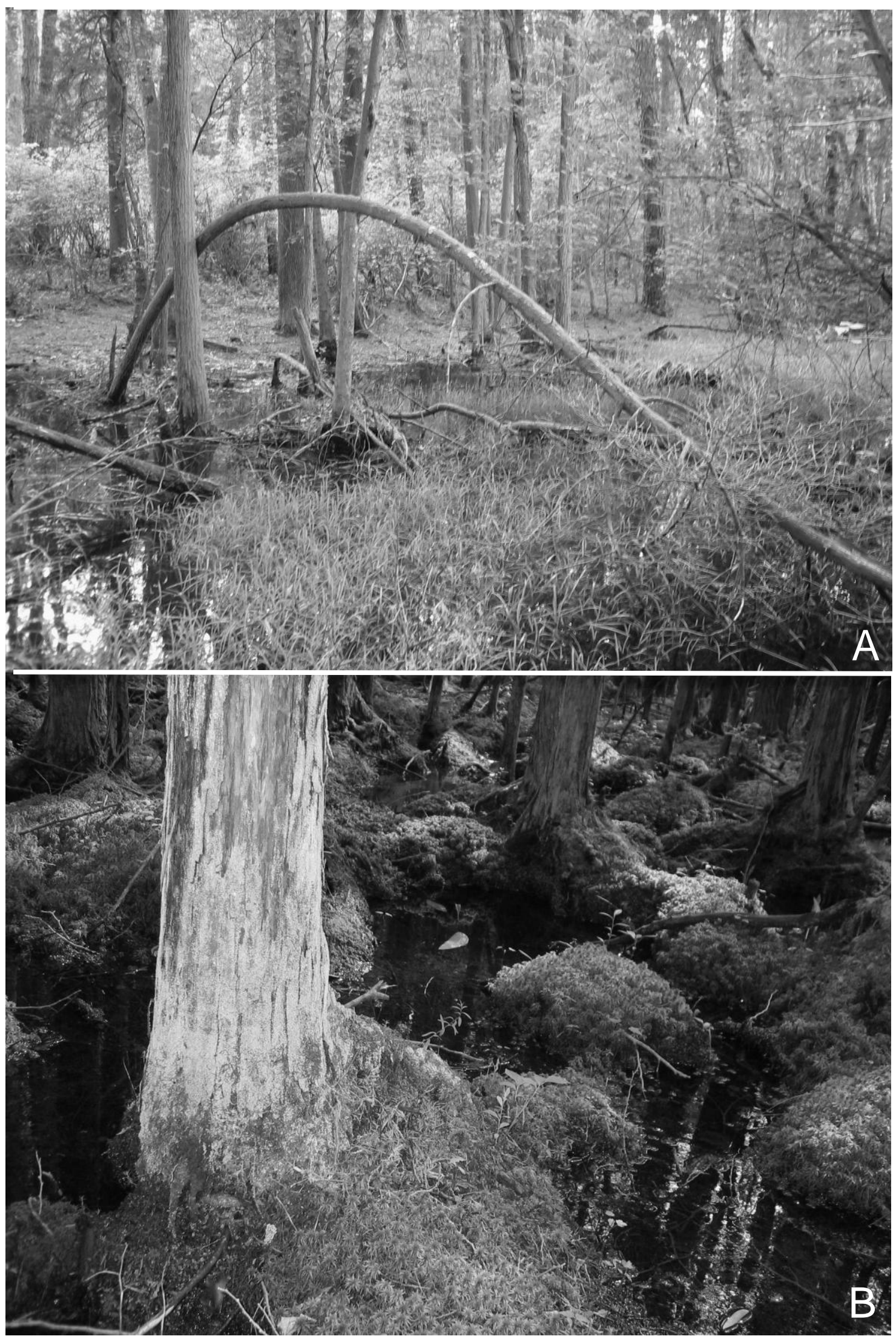


Figure 6. Fallen log at Winslow field site from which a Haemopis ottae specimen was collected. Although the log is saturated with water, it is not submerged. Arrow identifies an earth worm that was proximal to the collected leech. 


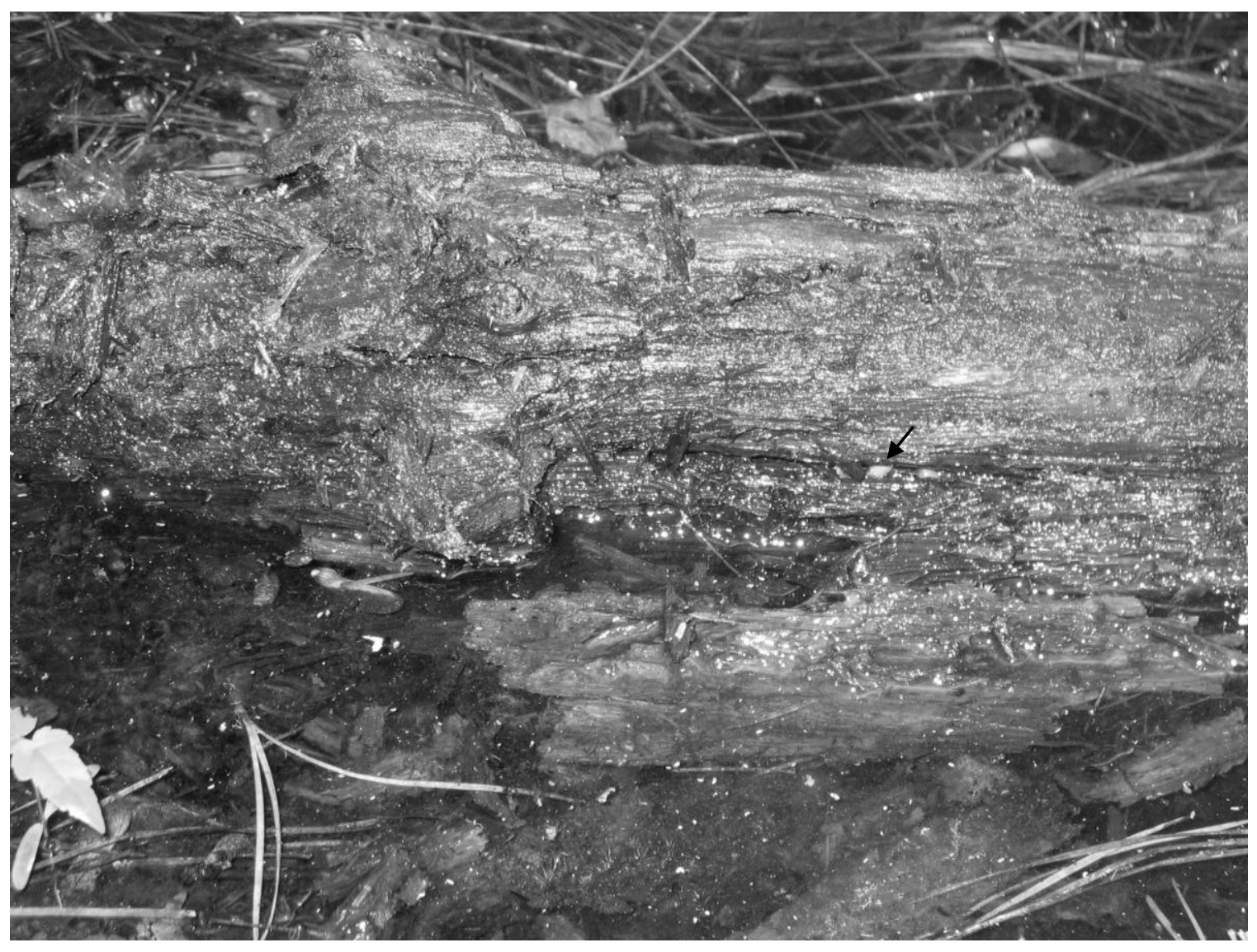


Figure 7. Phylogenetic tree of the combined data set resolving relationships within the genus Haemopis. Maximum Parsimony and Bayesian Inference analyses were performed on the combined data set (COI, 12S, 28S); posterior probabilities indicated above, and bootstrap values below branches. 
Mesobdella gemmata

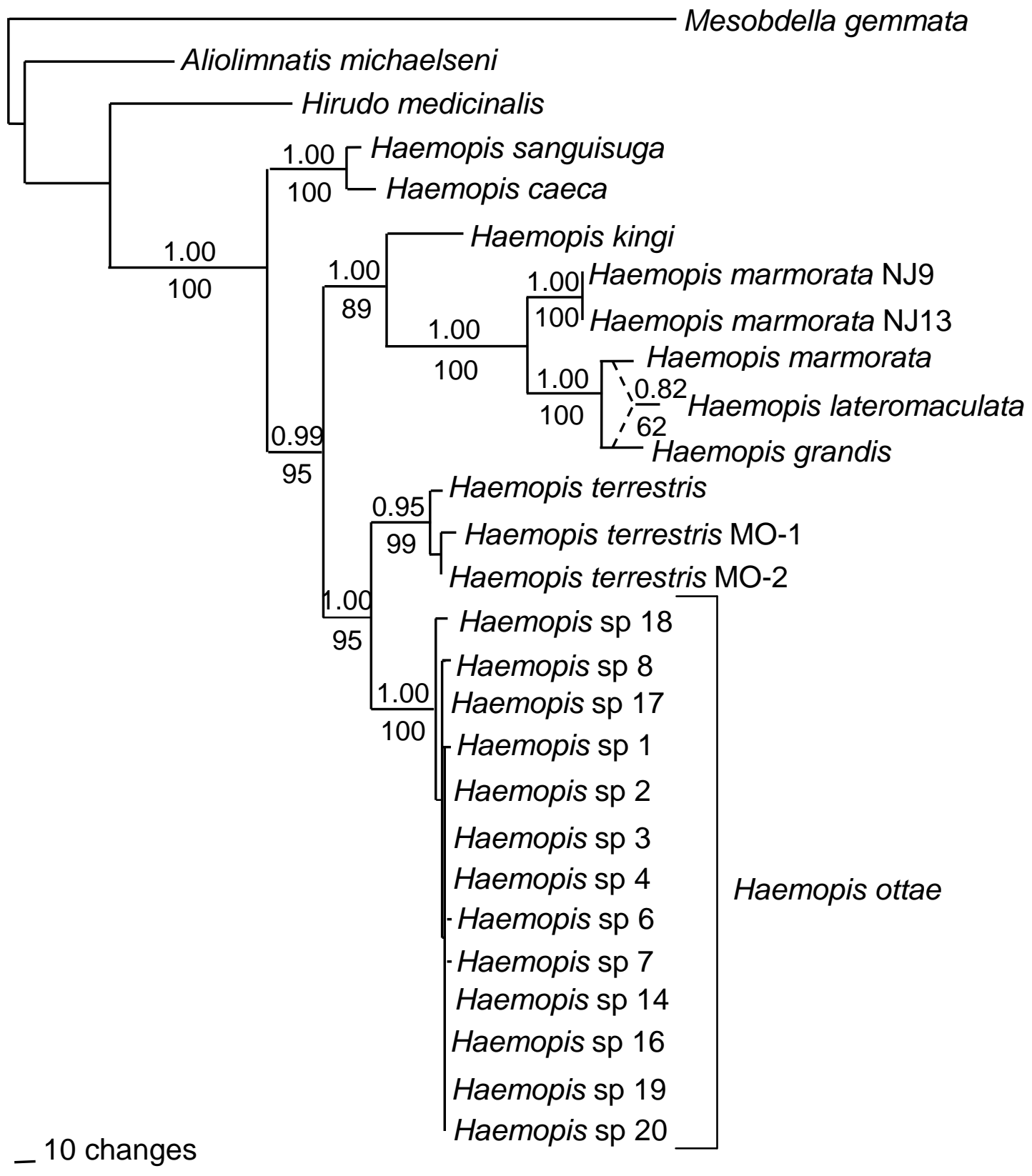


Figure 8. Most parsimonious tree obtained from cytochrome $c$ oxidase subunit 1 mtDNA, for the genus Haemopis. All Haemopis ottae samples are a clade sister to Haemopis terrestris. 


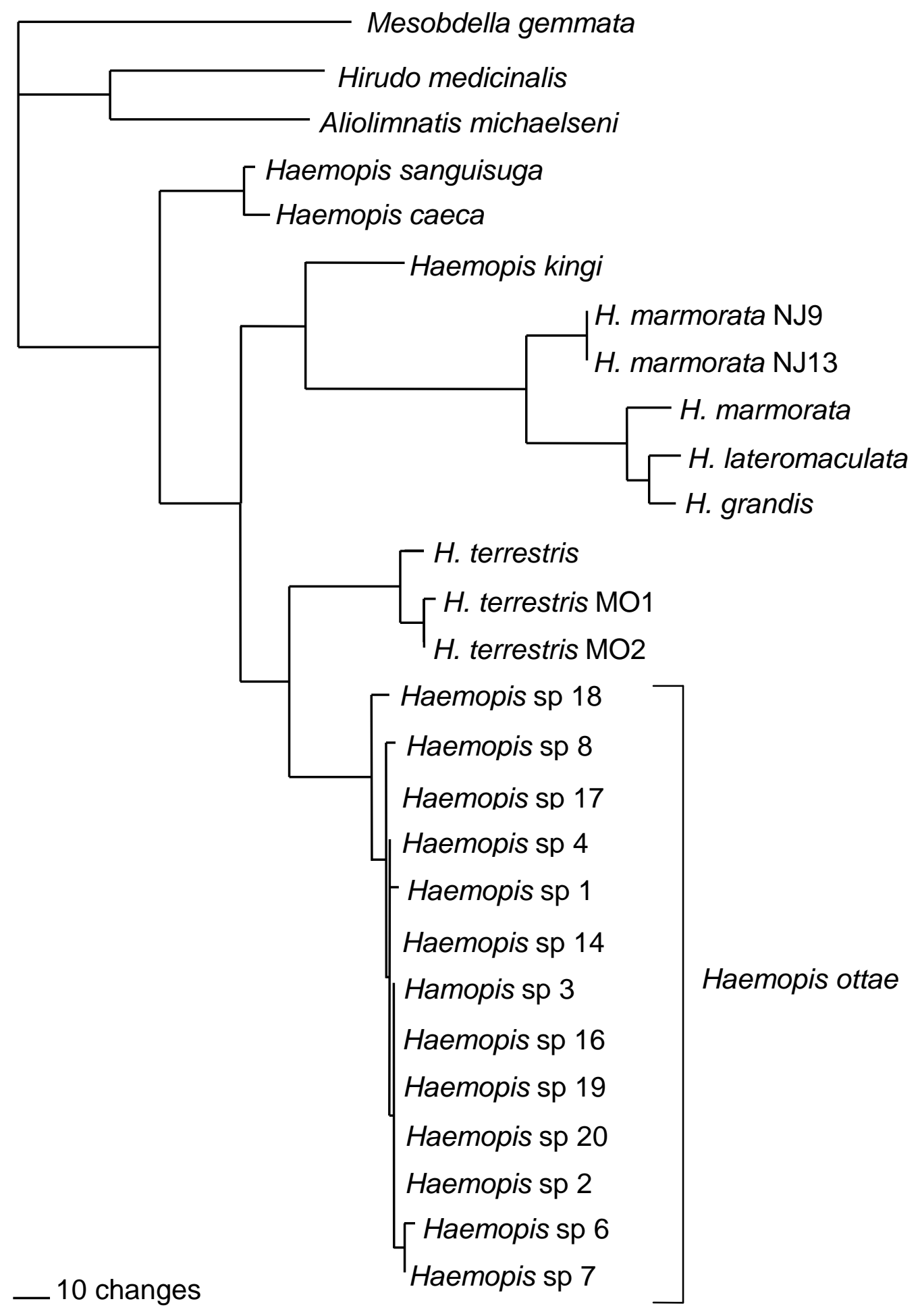


Figure 9. Most parsimonious tree obtained from 12S rDNA, for the genus Haemopis. All Haemopis ottae samples are a clade sister to Haemopis terrestris. 
Mesobdella gemmata

Aliolimnatis michaelseni

\section{Hirudo medicinalis}

Haemopis sanguisuga

Haemopis caeca

Haemopis kingi

$\mid \begin{aligned} & \text { Haemopis marmorata NJ9 } \\ & \text { Haemopis marmorata NJ13 } \\ & \text { Haemopis grandis lateromaculata } \\ & \begin{array}{l}\text { Haemopis terrestris } \\ \text { Haemopis sp } 1 \\ \text { Haemopis sp } 2 \\ \text { Haemopis sp } 4 \\ \text { Haemopis sp } 6 \\ \text { Haemopis sp } 7 \\ \text { Haemopis sp } 8 \\ \text { Haemopis sp } 14 \\ \text { Haemopis sp } 17\end{array}\end{aligned}$ 
Figure 10. Most parsimonious tree obtained from 28S rDNA, for the genus Haemopis. Multiple polytomies present indicating insufficient data to resolve relationships between closely related species. 


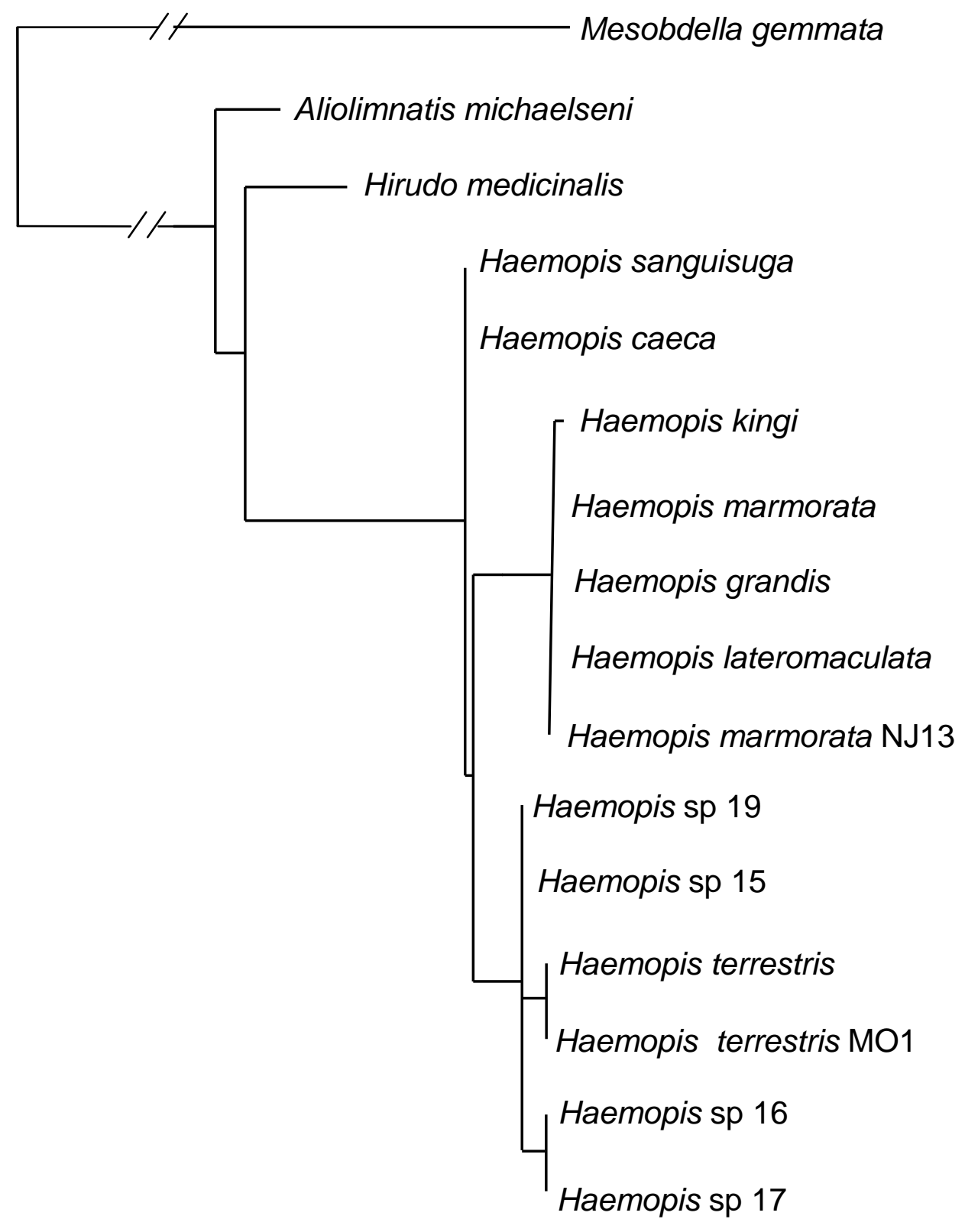

- 5 changes 
Figure 11. Sketches from dorsal and ventral views of adult Haemopis ottae type specimen from Alloway, NJ, viewed under enhanced artificial light. Insets are magnifications of anterior dorsum (A), and ventral gonopores (B). Faint, often broken midline and moderate to heavy black mottling present on dorsum. Seven annuli were present between gonopores, with male and female pores located in the furrow. White-tipped papillae ( 16 per annuli) present every fifth annulus; five pairs of eyespots in a classic Hirudinid arc. cs, caudal sucker; es, eyespot; n, nephridiopore; $p$, papillae. 


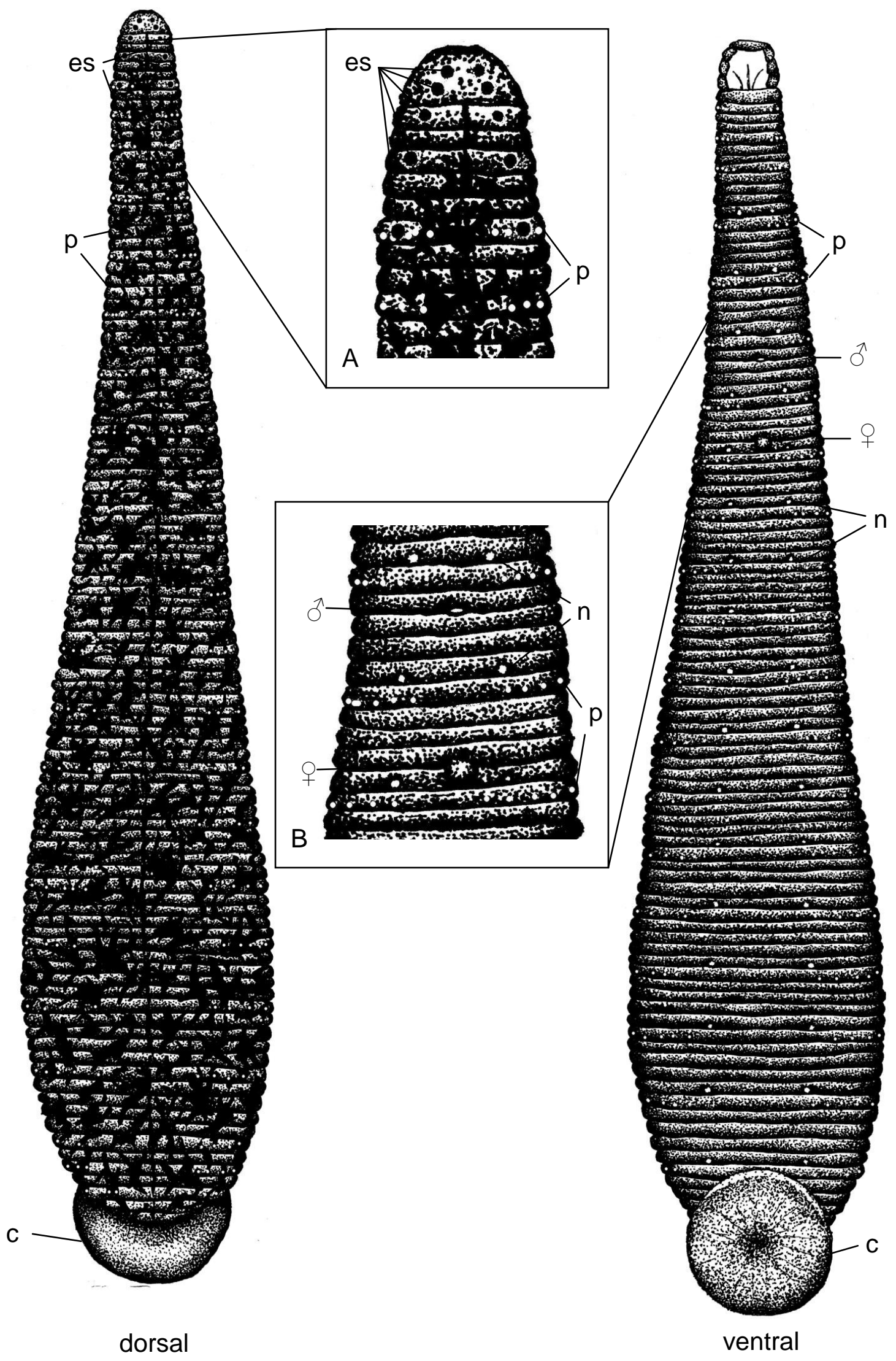


Figure 11. Photograph of live Haemopis ottae. Specimen collected at the Winslow field site from inside a decaying log. Photograph taken by Avi Steinhardt, Courier Post. 


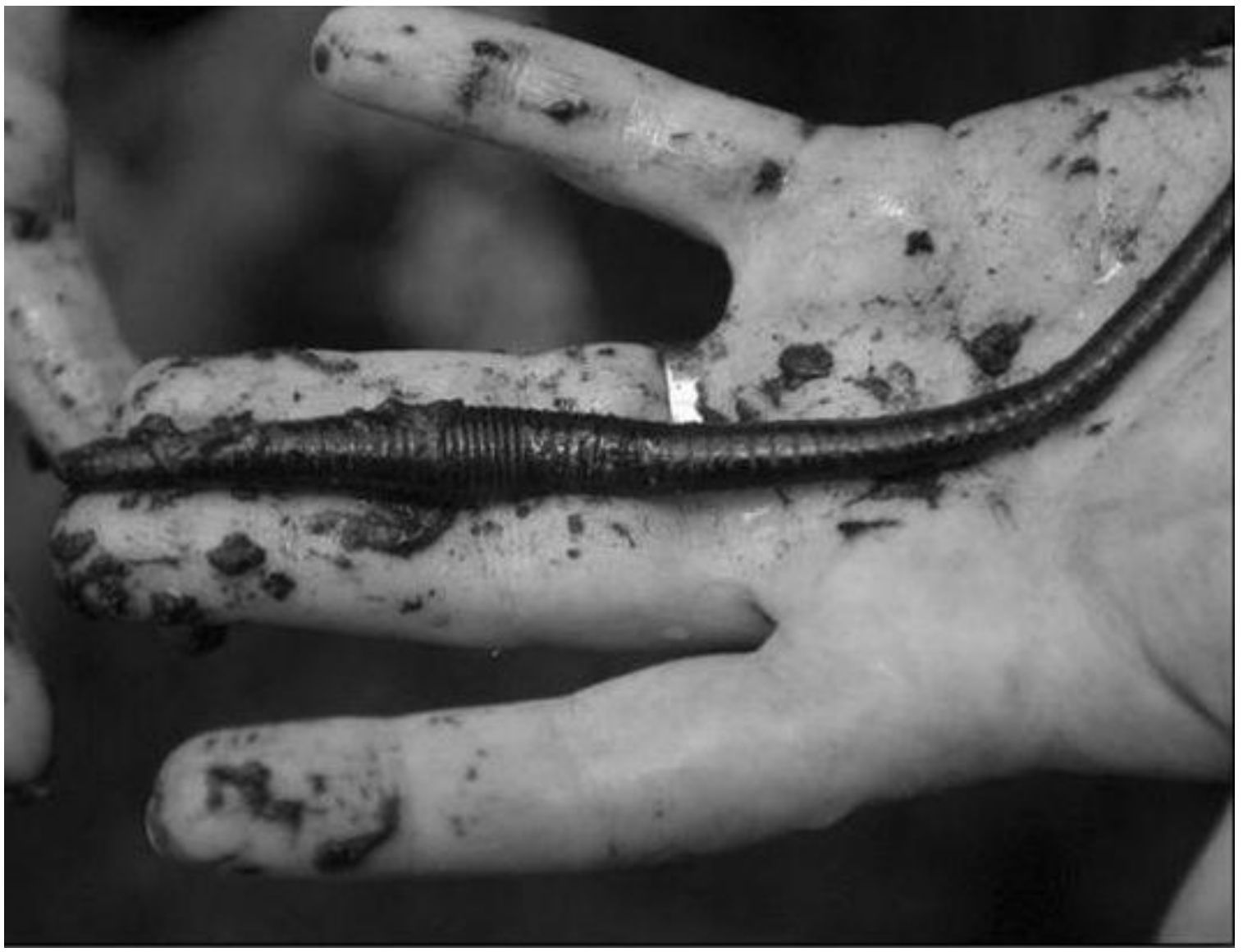


Figure 9. Sketches made from dorsal view of reproductive structures. (A) Haemopis ottae. (B) Haemopis marmorata-like specimen found in Camden, NJ. (C) Haemopis terrestris collected from Belton, Missouri. H. ottae epididymis was notably large, extending far past the sperm sac; vaginal duct and oviduct were relatively straight and uncoiled, ovaries were significantly small, vagina was narrow and less pronounced. e, epididymis; g, ganglion; o, ovary; od, oviduct; os, ovisac; ps, penis sheath; pg, prostate gland; ss, sperm sac; t, testis; v, vagina; vd, vaginal duct; ve, vas eferens. 


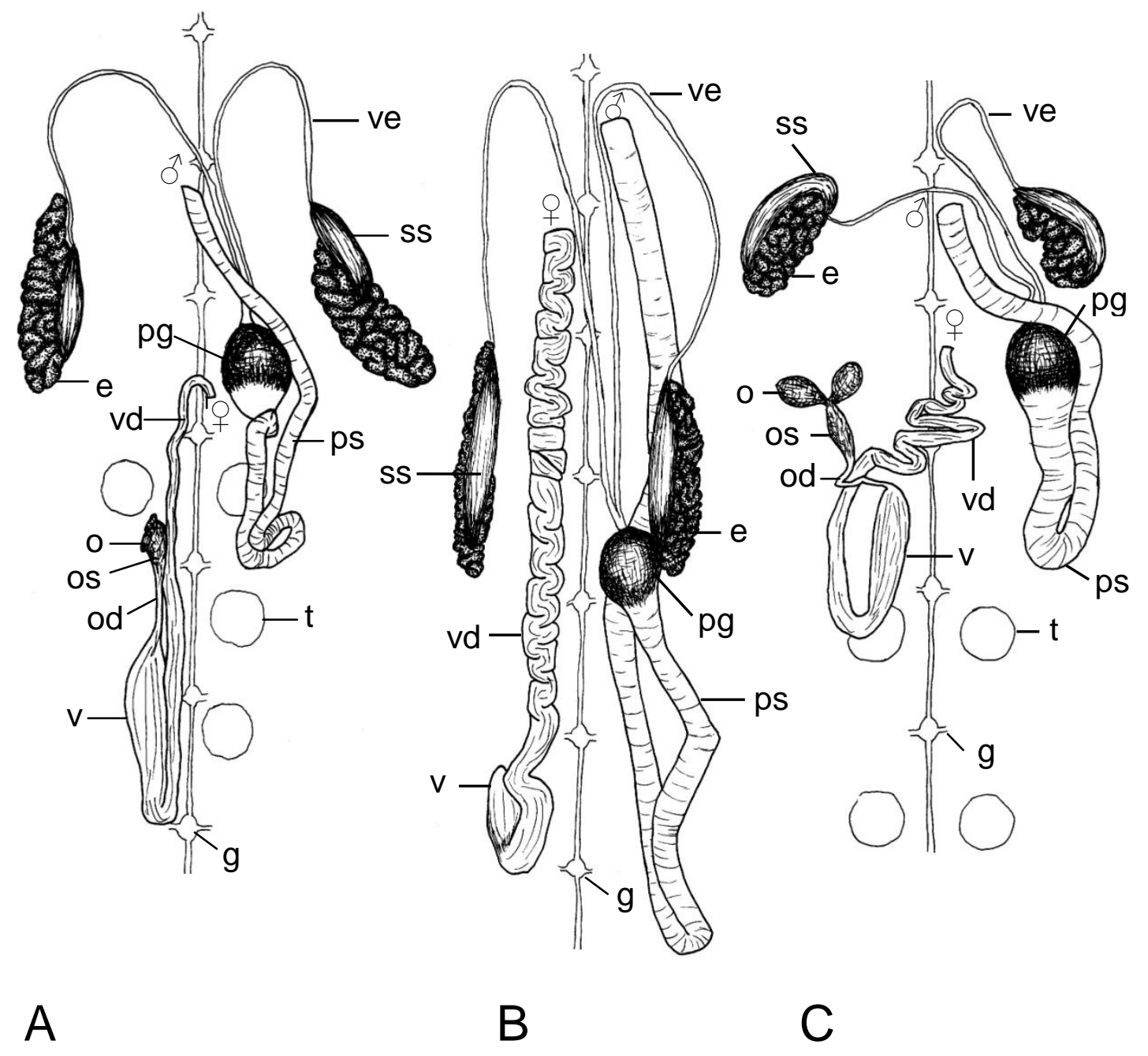


Figure 13. Map depicting the putative evolutionary history of terrestrial leeches in North America. Distributions of Haemopis terrestris and Haemopis septagon are from Klemm (1986) and Sawyer and Shelly (1976), respectively. Shaded area represents the Appalachian Range. Haemopis ottae; Haemopis terrestris; Haemopis septagon. 


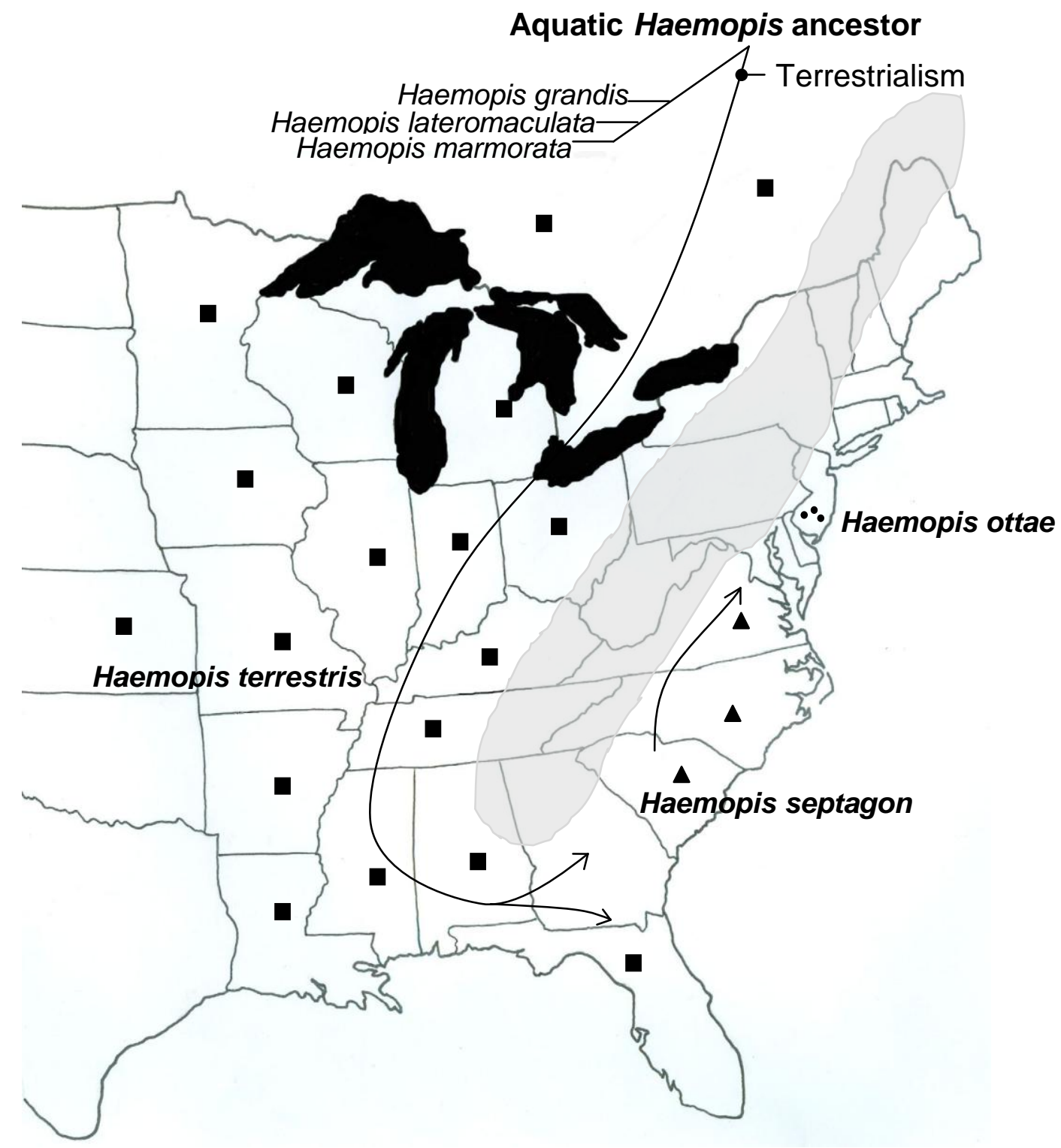

